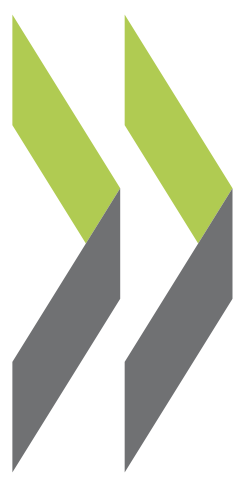

OECD Economics Department Working Papers No. 1217

\title{
A Snapshot of China's \\ Service Sector
}

Margit Molnar,

Wei Wang 


\section{Unclassified}

ECO/WKP(2015)35

Organisation de Coopération et de Développement Économiques

Organisation for Economic Co-operation and Development

29-Oct-2015

ECONOMICS DEPARTMENT

English - Or. English

Cancels \& replaces the same document of 22 May 2015

A SNAPSHOT OF CHINA'S SERVICE SECTOR

ECONOMICS DEPARTMENT WORKING PAPERS No. 1217

By Margit Molnar and Wei Wang

OECD Working Papers should not be reported as representing the official views of the OECD or its member countries. The opinions expressed and arguments employed are those of the author $(s)$.

Authorised for publication by Robert Ford, Deputy Director, Country Studies Branch, Economics Department.

All OECD Economics Department Working Papers are available at www.oecd.org/eco/workingpapers

JT03385329

Complete document available on OLIS in its original format

This document and any map included herein are without prejudice to the status of or sovereignty over any territory, to the delimitation of international frontiers and boundaries and to the name of any territory, city or area. 
OECD Working Papers should not be reported as representing the official views of the OECD or of its member countries. The opinions expressed and arguments employed are those of the author(s).

Working Papers describe preliminary results or research in progress by the author(s) and are published to stimulate discussion on a broad range of issues on which the OECD works.

Comments on Working Papers are welcomed, and may be sent to the Economics Department, OECD, 2 rue André-Pascal, 75775 Paris Cedex 16, France, or by e-mail to eco.contact@ oecd.org.

This document and any map included herein are without prejudice to the status of or sovereignty over any territory, to the delimitation of international frontiers and boundaries and to the name of any territory, city or area.

The statistical data for Israel are supplied by and under the responsibility of the relevant Israeli authorities. The use of such data by the OECD is without prejudice to the status of the Golan Heights, East Jerusalem and Israeli settlements in the West Bank under the terms of international law.

\section{(C) OECD (2015)}

You can copy, download or print OECD content for your own use, and you can include excerpts from OECD publications, databases and multimedia products in your own documents, presentations, blogs, websites and teaching materials, provided that suitable acknowledgment of OECD as source and copyright owner is given. All requests for commercial use and translation rights should be submitted to rights@oecd.org 
ECO/WKP(2015)35

\section{ABSTRACT/RÉSUMÉ}

\section{A snapshot of China's service sector}

The share of the tertiary sector in China's value added has increased steadily, overtaking the share of the secondary sector in 2013. With increasing incomes, the share of services is expected to grow further as at higher incomes a larger share of income is spent on services. In addition to final demand, intermediate demand can be another driving force for service industries. As liberalisation leads to a greater role for the market in allocating resources, service industries are expected to become more competitive and therefore it may become cheaper to outsource services than to produce them in-house. Liberalisation will likely also lead to greater specialisation to remain competitive, thereby making specialised services available for outsourcing. This will likely spur the development of some high value-added logistics services such as warehousing or order handling. By the same token, professional services such as accounting or engineering are also likely to benefit from a greater reliance on the market and greater competition. In the envisaged transition from "made in China" to "created in China", the service sector is expected to play a prominent role. To that end, the service sector is gradually being provided a more even playing field as privileges for manufacturing industries are being withdrawn and a more equal treatment of producers across sectors is being adopted. This paper provides a snapshot of the service sector, its size, the ownership of its firms, and productivity across types of firms depending on ownership, sector, age, size and geographical region.

This Working Paper relates to the 2015 OECD Economic Survey of China

www.oecd.org/eco/surveys/economic-survey-china.htm.

JEL classification: L80, L81, L84, L90, J24, L11, L50.

Keywords: China, services, labour productivity, firm-level analysis, state-owned enterprises, regulation, logistics, transport, distribution, professional services.

***************************************

\section{Un état des lieux du secteur des services en Chine}

La part du secteur tertiaire dans la valeur ajoutée de la Chine n'a cessé de croître pour dépasser celle du secteur secondaire, en 2013. Compte tenu de l'augmentation des revenus, la part des services devrait continuer de progresser car plus le revenu est élevé, plus les dépenses consacrées aux services augmentent. Outre la demande finale, la consommation intermédiaire devrait constituer un autre facteur de consommation à la hausse de services. Les mesures de libéralisation laissant un plus grand rôle au marché dans l'allocation des ressources, le secteur des services devrait gagner en compétitivité et c'est pourquoi leur externalisation pourrait désormais coûter moins cher que leur production en interne. Pour préserver la compétitivité, la libéralisation entraînera également une plus grande spécialisation et des services spécialisés s'offriront ainsi à l'externalisation. Le développement de certains services logistiques à forte valeur ajoutée, comme la gestion d'entrepôts ou de commandes, devrait s'en trouver très certainement stimulé. De même, il est probable que les services de professions spécialisées comme la comptabilité et l'ingénierie bénéficieront eux aussi d'un plus large recours aux mécanismes du marché et d'une concurrence renforcée. Le secteur des services entend jouer un rôle de premier plan dans la future transition du « fabriqué en Chine » au «créé en Chine ». Dans cette optique, ce secteur voit s'instaurer peu à peu des règles de jeu plus égales, les industries manufacturières se voyant retirer certains de leurs privilèges et le principe d'égalité de traitement des producteurs entre les secteurs étant adopté. Ce document dresse un état de lieux du secteur des services et analyse sa taille, les structures de propriété de ses entreprises et la productivité de différents types d'entreprises en fonction de leur propriété, leur activité, leur ancienneté, leur taille et leur région.

Ce document de travail se rapporte à l'Étude économique de la Chine, OCDE, 2015

www.oecd.org/fr/eco/etudes/etude-economique-chine.htm.

Classification JEL : L80, L81, L84, L90, J24, L11, L50.

Mots-clés : Chine, services, productivité du travail, analyse microéconomique, entreprises publiques, réglementation, logistique, transport, distribution, services professionnels. 


\section{TABLE OF CONTENTS}

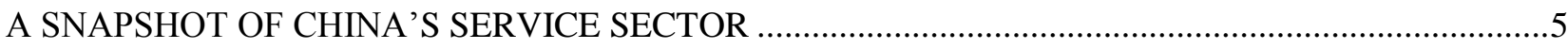

The "servisification" of the Chinese economy is making headway ...........................................................5

The share of services in value added now exceeds that of manufacturing...........................................5

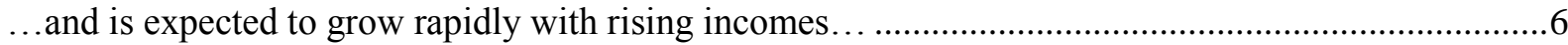

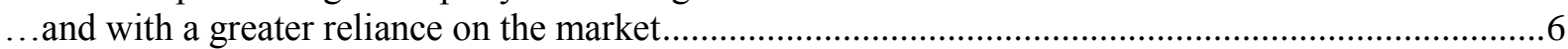

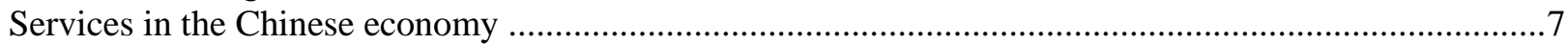

Service firms are smaller, younger, mostly engaged in sales and are concentrated in developed regions 8

Productive service firms are small and between five and 15 years old .................................................

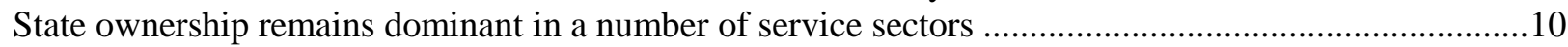

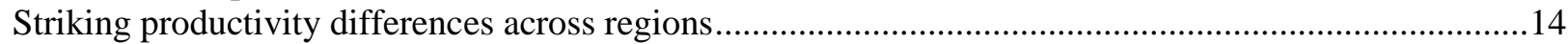

Regulations and productivity patterns vary widely across service industries .....................................19

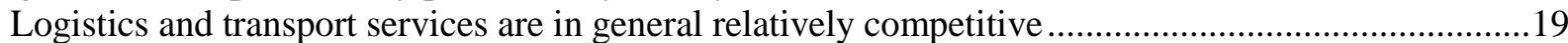

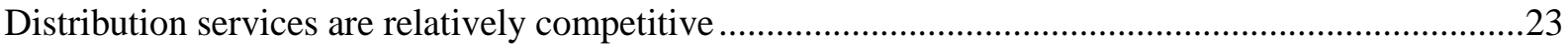

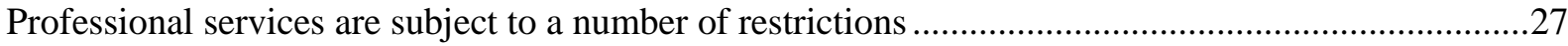

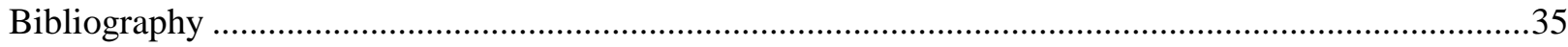

\section{Tables}

1. Composition of entities according to the 2008 Economic Census .......................................................

\section{Figures}

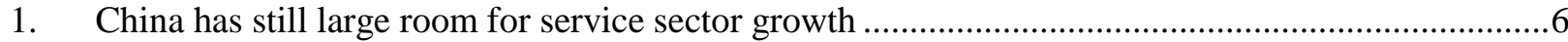

2. Distribution of the 2.7 million service firms by size, age, sector and province.................................

3. Productive service firms are small and between five and 15 years old .......................................10

4. China appears restrictive on the public ownership indicator ......................................................11

5. SOEs are dominant in a number of service sectors ....................................................................12

6. SOEs are dominant among larger or well-established firms and in several provinces....................13

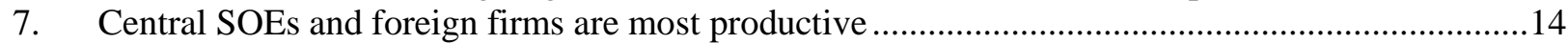

8. Geographical productivity differences are driven by within-province disparities...........................16

9. Productivity differences at county level are also driven by between-county differences.................18

10. Entry to the road transportation business is highly restricted ......................................................20

11. Two- to 15-year old firms are most productive, while size does not appear to matter for

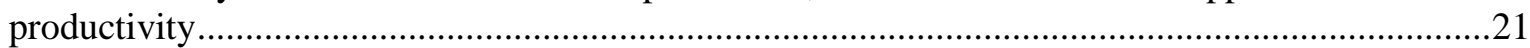

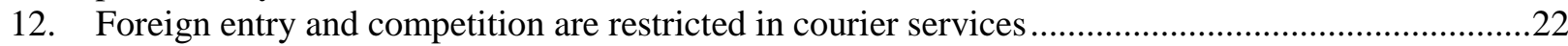

13. Experience and location matters most for express delivery productivity .......................................23

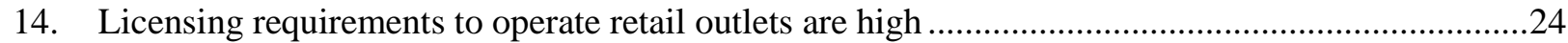

15. Foreign-invested groceries and supermarkets are the most productive ........................................25

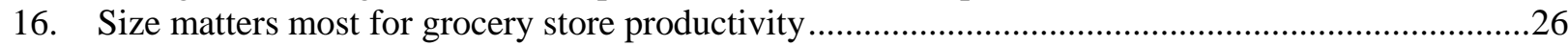

17. Department store productivity appears to increase with size .........................................................27

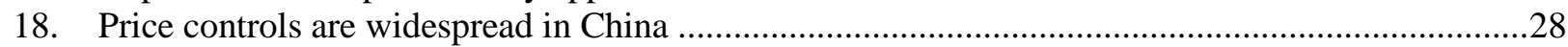

19. Command-type regulation is more common in China than in many OECD countries....................29

20. The administrative burden on sole proprietorship start-ups is prohibitively high ..........................30

21. Trade in architecture services is mainly hindered by restrictions on movement of people ..............31

22. Restrictions on movement of people are also hindering trade in engineering services ....................31

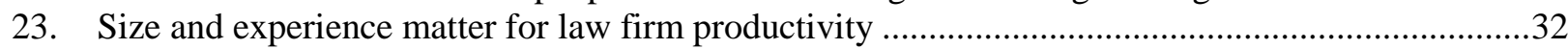

24. Larger and older accounting firms are more productive.............................................................33

25. Large and well-established architecture and engineering firms are more productive .....................34 
ECO/WKP(2015)35

\title{
A SNAPSHOT OF CHINA'S SERVICE SECTOR
}

\author{
By Margit Molnar and Wei Wang ${ }^{1}$
}

1. In the envisaged transition from "made in China" to "created in China", the service sector is expected to play a prominent role. To that end, the service sector is gradually being provided a more even playing field as privileges for manufacturing industries are being withdrawn and a more equal treatment of producers across sectors is being adopted. This paper provides a snapshot of the service sector, its size, the ownership of its firms, and productivity across types of firms depending on ownership, sector, age, size and region.

\section{The "servisification" of the Chinese economy is making headway}

\section{The share of services in value added now exceeds that of manufacturing...}

2. The share of the tertiary sector in value added has increased steadily, overtaking the share of the secondary sector in 2013. According to the official definition, the share of the tertiary industry reached $48.2 \%$ in 2014 , while that of the secondary industry was $42.6 \%$ and of agriculture $9.2 \%$. It is worth noting that in China, mining, manufacturing, electricity, water, gas and construction are classified as secondary industries, implying that the size of the service sector according to the international classification is larger. The share of services is likely to be underestimated for another reason as well: firms are classified into sectors according to their main activity. Thus, if the first activity is manufacturing and the second is services, the entire activity of the firm will be classified under manufacturing. Although this classification is common in most countries, in China, large firms have traditionally provided many services in-house instead of outsourcing them. At a stage of economic development where markets play less of a role in the allocation of resources, transaction costs tend to be higher; hence it is more costly to outsource services. According to a 2008 survey of 100 firms in six major industries, many firms (81\%) outsource transportation-related parts of their supply chain, but higher value-added services such as warehousing, packaging, order handling and accounting functions are much less likely to be outsourced (A.T. Kearney, 2009). The low level of service outsourcing thus also reduces the reported size of the services sector.

3. The ongoing 2011-15 Five-Year Plan mentions services sector development as a priority, recognising the importance services can play in boosting overall productivity and driving growth. The backwardness of the service sector has sometimes been pointed out as a drag on overall growth. In addition to its small size, its structure is not healthy as commercial services that would increase manufacturing productivity, such as research and development, logistics, accounting, auditing, consultancy and financial services are underdeveloped (Zhang, 2011). The relative backwardness of services as opposed to manufacturing is also related to the greater focus on manufacturing in the past decades and preferential policies such as the pricing of electricity, water or land use. The tax system that was in place until 2012 (when piloting of the conversion of the business tax into a value added tax started in Shanghai), with the business tax levied on services and the value added on manufacturing, has also been restricting the growth

1. Margit Molnar heads the China desk in the OECD Economics Department and Dr. Wei Wang is Deputy Director of the Market Economy Research Institute, Development Research Centre of the State Council in Beijing. This paper was originally produced as a background document for the 2015 OECD Economic Survey of China published in March 2015 under the authority of the Economic and Development Review Committee (EDRC). The authors thank Alvaro Pereira, Robert Ford, Vincent Koen, Ben Westmore and Hildegunn Nordas as well as officials from the Chinese government for valuable comments on earlier drafts, and Thomas Chalaux for statistical and Nadine Dufour and Mercedes Burgos for editorial assistance. 
of services. Since 2001, the tax burden of the tertiary sector has exceeded that of the secondary sector and that there is no tax refund policy on labour inputs used for services exports or on services provided offshore (Zhang, 2011). The business tax applies regardless of where the service itself is rendered. Moreover, as service industries were not taxed under the VAT system, they could not get a refund on intermediate inputs as manufacturing firms could.

\section{....and is expected to grow rapidly with rising incomes...}

4. With increasing incomes, the share of services is expected to grow further as at higher incomes a larger share of income is spent on services. The experience of other countries shows that when a country reaches a per capita income of USD 30000 in PPP terms, its services share is typically between 60 and $85 \%$ of GDP (Figure 1). Most high-income OECD members have services shares of around $70 \%$ or higher, including manufacturing powerhouses like Germany or Japan.

Figure 1. China has still large room for service sector growth Share of services in value-added versus GDP per capita in PPP dollars

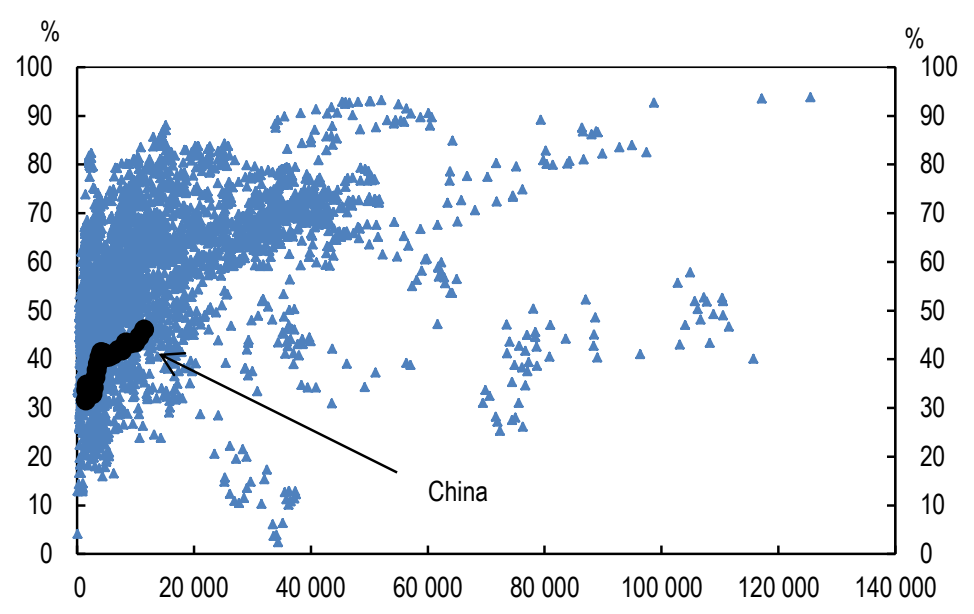

Note: All countries available over 1990-2013. China is marked in black.

Source: World Bank World Development Indicators database.

\section{....and with a greater reliance on the market}

5. In addition to final demand, intermediate demand can be another driving force for service industries. As liberalisation leads to a greater role for the market in allocating resources, service industries are expected to become more competitive and therefore it may become cheaper to outsource services than to produce them in-house. In addition, liberalisation will likely lead to greater specialisation to remain competitive, thereby making specialised services available for outsourcing. This will likely spur the development of some high value-added logistics services such as warehousing or order handling. By the same token, professional services such as accounting or engineering are also likely to benefit from a greater reliance on the market and greater competition.

6. Furthermore, with structural and demographic transformation, and rising incomes, demand for healthcare, culture, education and commercial services is expected to rise. Adequate standards for service quality, environmental regulation and consumer protection are important in those sectors to avoid damaging competition when they open up.

7. The expansion of services is beneficial for meeting job creation as well as environmental targets as service industries in general tend to be labour-intensive and less polluting than manufacturing. A more 
efficient service sector will also accelerate the upgrading of other sectors. For instance, agricultural productivity can be boosted by removing existing bottlenecks such as fragmented transportation networks and the lack of sufficient cold-storage infrastructure. It is also often recognised that without a developed and competitive service sector manufacturing growth can only rely on volume but not adding value. R\&D, innovation, patents, trademarks, design, distribution, logistics and software account for about $90 \%$ of value added and therefore an underdeveloped service sector constitutes a drag on moving up the value chain.

\section{Services in the Chinese economy}

8. The major source of data used for the analysis in this paper is the 2008 Economic Census covering over seven million entities, including roughly five million firms (Table 1). Although the Chinese economy has undergone profound changes since 2008, this Census is the most recent database available that covers all firms. Moreover, it allows getting an insight into ownership structures and the size, age and regional dimensions of firms and their activities. The aggregate results of the 2013 Economic Census have just been released (National Bureau of Statistics of China and Office of the Leading Group of the State Council for the Third National Economic Census, 2014) and show that the number of entities increased by over 50\% and the number of firms over 60\% during 2008-13. No revenue or productivity details have so far been disclosed and the data are not available for analysis yet.

Table 1. Composition of entities according to the 2008 Economic Census

\begin{tabular}{lrr}
\hline & Number of entities (million) & Share (\%) \\
Legal persons & 7.099 & 100 \\
Corporations & 4.96 & 69.9 \\
Departments and institutions & 0.96 & 13.5 \\
Social organisations and others & 1.18 & 16.6 \\
Establishments & 8.86 & 100 \\
Secondary industry & 2.30 & 25.9 \\
Tertiary industry & 6.56 & 74.1 \\
Self-employed individuals with licenses & 28.74 & 100 \\
Secondary industry & 2.54 & 8.8 \\
Tertiary industry & 26.20 & 91.2 \\
\hline
\end{tabular}

Note: The definition of tertiary industry follows the Chinese national categories, i.e. construction and utilities are not included. Source: Office of the Leading Group of the State Council for the Second National Economic Census and National Bureau of Statistics of China (2010), Communiqué on Major Data of the Second National Economic Census of China, China Statistics Press.

9. For the purposes of this paper, the Chinese national industrial classification is converted to the United Nations ISIC Rev. 3 categories and firms belonging to categories of 40 and above are classified as service firms. Public and personnel services are not included in the analyses, thus only services from ISIC Rev. 3 category 40 to 74 are used. As the two-digit categories are often too heterogeneous, four-digit categories are used alongside two-digit ones. The analysis focuses on firms that operated throughout 2008 and excludes the ones that had been in the process of establishment or closure or that suspended their operations in that year. Services can be provided not only by firms but also by other legal entities such as institutions, agencies or social organisations; those providers are not included in the analysis. Also, selfemployed individuals with licences to provide services are not included due to a lack of rigorous reporting requirements for such individuals. Productivity is defined as revenue per employee throughout the paper. This measure has some shortcomings owing to the fact that it is not based on value added (for which much fewer observations are available and data quality - partly due to measurement issues - is weaker). For example, in services with high intermediate inputs such as retail or other trading activities, firms may appear more productive than in services such as architecture or other professional services where the share of intermediate inputs is lower. This caveat needs to be borne in mind in particular when making comparisons across service industries. 


\section{Service firms are smaller, younger, mostly engaged in sales and are concentrated in developed regions}

10. There are 2.7 million service firms in China, making up around $61 \%$ of all firms. Firms in the service sector tend to be smaller than in other sectors, with over three-quarters being micro enterprises (fewer than 20 employees), in contrast to a share of $66 \%$ of micro-enterprises in the total (defined as United Nations ISIC Rev. 3 categories 1-74) (Figure 2.A). This can be explained by relatively low entry costs including low fixed asset requirements in several service industries and a lesser importance of

Figure 2. Distribution of the 2.7 million service firms by size, age, sector and province

Share in total service firms, 2008

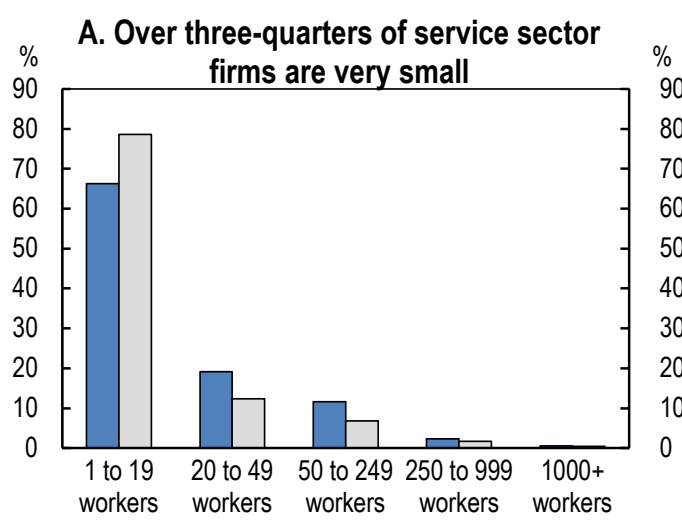

$\square$ Percent of total firms $\square$ Percent of services firms

\section{Around half of service sector firms} are engaged in sales

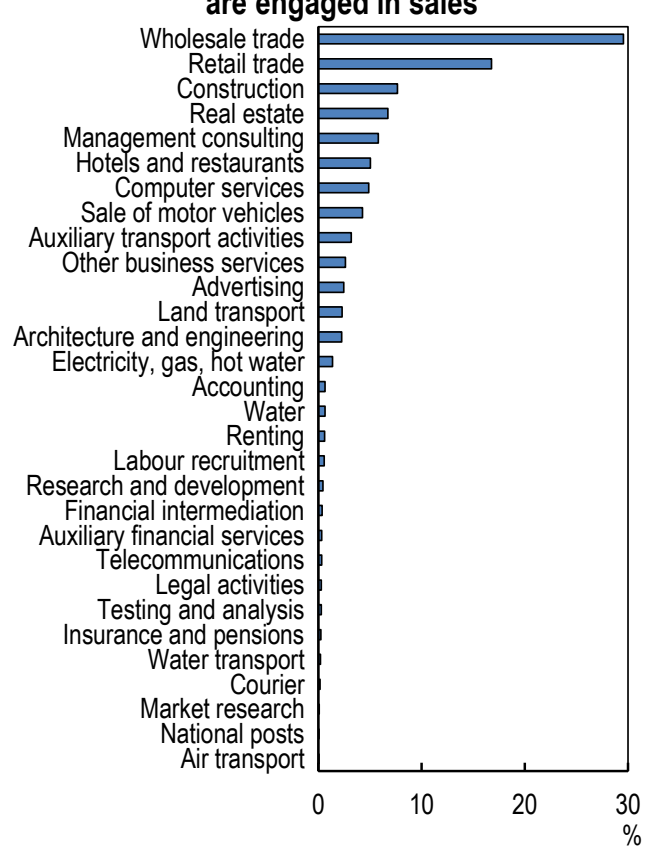

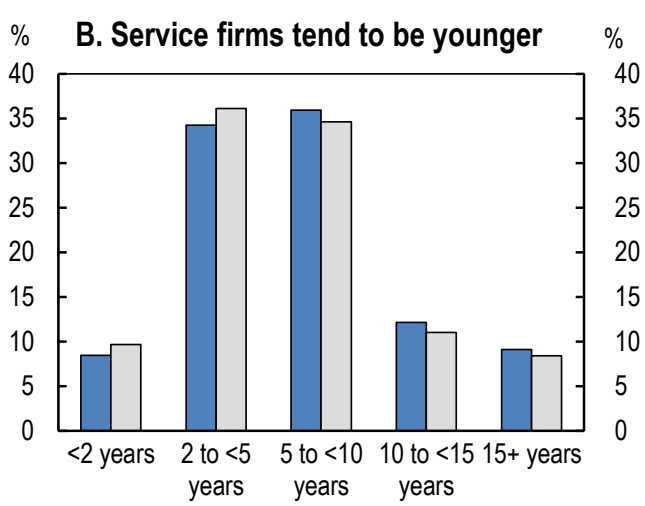

$\square$ Percent of total firms $\square$ Percent of services firms

\section{Shanghai and Beijing are more} service oriented

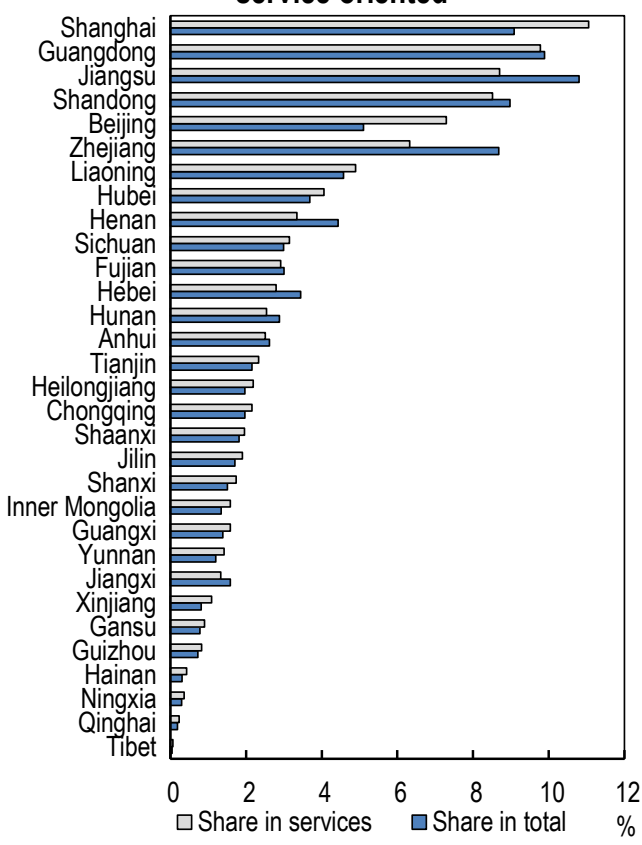

Note: Sectors are classified according to the United Nations ISIC Rev. 3 two-digit sector codes except for the following services, which are classified according to the four-digit sector codes: national post, courier services, legal activities, accounting and auditing, architecture and engineering, advertising, market research, labour recruitment, testing and analysis, and management consultancy. The total includes categories 1-74 in the United Nations ISIC Rev. 3 classification.

Source: Authors' calculations based on the 2008 Economic Census. 
economies of scale in production (Molnar and Bottini, 2010 did not find significant scale effects in service industries in OECD countries). Furthermore, over $80 \%$ of service firms are less than 10 years old and their share among firms below 5 and below 2 years old is greater than that of other firms (Figure 2.B). Roughly half of all service sector firms are engaged in sales as major activity (Figure 2.C). There is also a large number of real estate, construction and management consulting firms. As most firms engage in sales and are relatively young, this may be related to low entry barriers to retail and wholesale trade and hence the emergence of many new firms. Also, many service firms are established by families and stay to support the family instead of expanding.

\section{Productive service firms are small and between five and 15 years old}

11. Service industries appear to become less productive with an increasing number of workers (Figure 3.A). This is the case of private firms, which outnumber all other ownership categories. Collectively-owned firms also exhibit similar overall patterns, while SOEs and foreign firms appear to be more productive if they are larger. Micro-firms with less than 20 employees are the most productive and their share in the total is the highest. The most productive firms are between five and 15 years old (Figure 3.B). There is a roughly five-fold difference in service sector productivity between firms in the most and the least productive province (Jilin and Qinghai) (Figure 3.C). Moreover, while some of the provinces with the least productive firms also have low incomes and are located in the Western part of the country, average service sector productivity is low in Beijing as well. By the same token, there are some Western and Central provinces with relatively low incomes among the provinces with the most productive service firms such as Inner Mongolia or Jiangxi. Thus service sector productivity, income levels and service-orientation are not necessarily linked. As mentioned at the outset, comparison of productivity across sectors is subject to the caveat of using revenue and not value added per worker as a measure of productivity and this not taking into account differences in intermediate inputs across sectors. 
Figure 3. Productive service firms are small and between five and 15 years old

Median revenue per worker by firm size, age and province, 2008
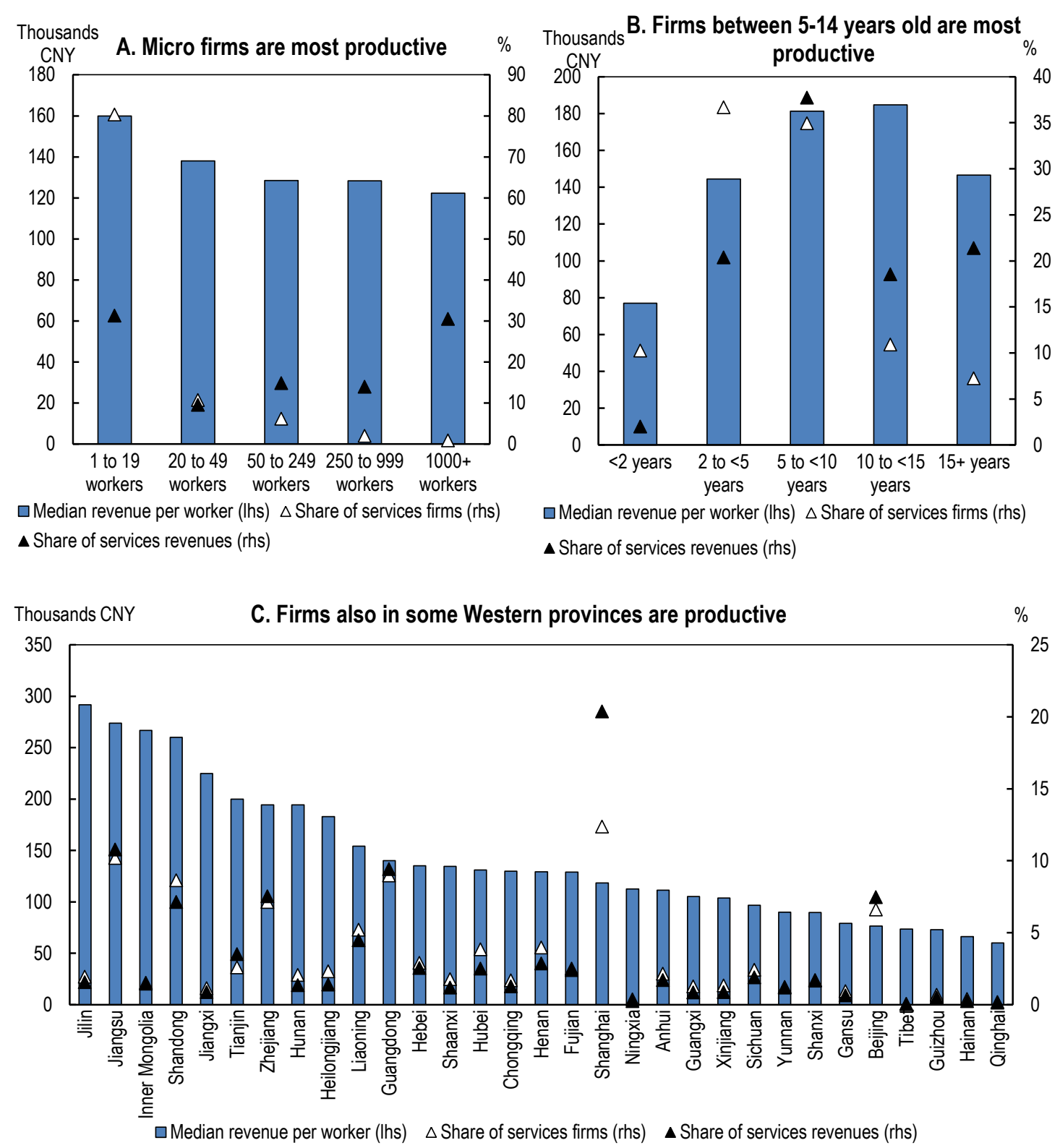

Note: Service industries are defined according to the international practice, i.e. all firms in the United Nations ISIC Rev. 3 classification with categories from 40 to 74 make part of the analyses. Panel C shows the provincial distribution of firms and revenues.

Source: Authors' calculations based on the 2008 Economic Census.

\section{State ownership remains dominant in a number of service sectors}

12. China scores very high (i.e. being very restrictive) on the public ownership component of to the OECD Product Market Regulatory (PMR) indicators with only Indonesia and Poland being even higher, although the value of the indicator has been somewhat reduced over 2008-13 (Figure 4). The high score of this component is largely explained by the large scope of SOEs, which is captured by a sub-indicator with a value of six - the most restrictive value the indicator can take. The government appears to be involved in 
network sector operations more frequently than in OECD countries and can for instance, overturn the decision of the regulator.

Figure 4. China appears restrictive on the public ownership indicator

The product market regulatory indicator on public ownership in the economy, 2008 and 2013

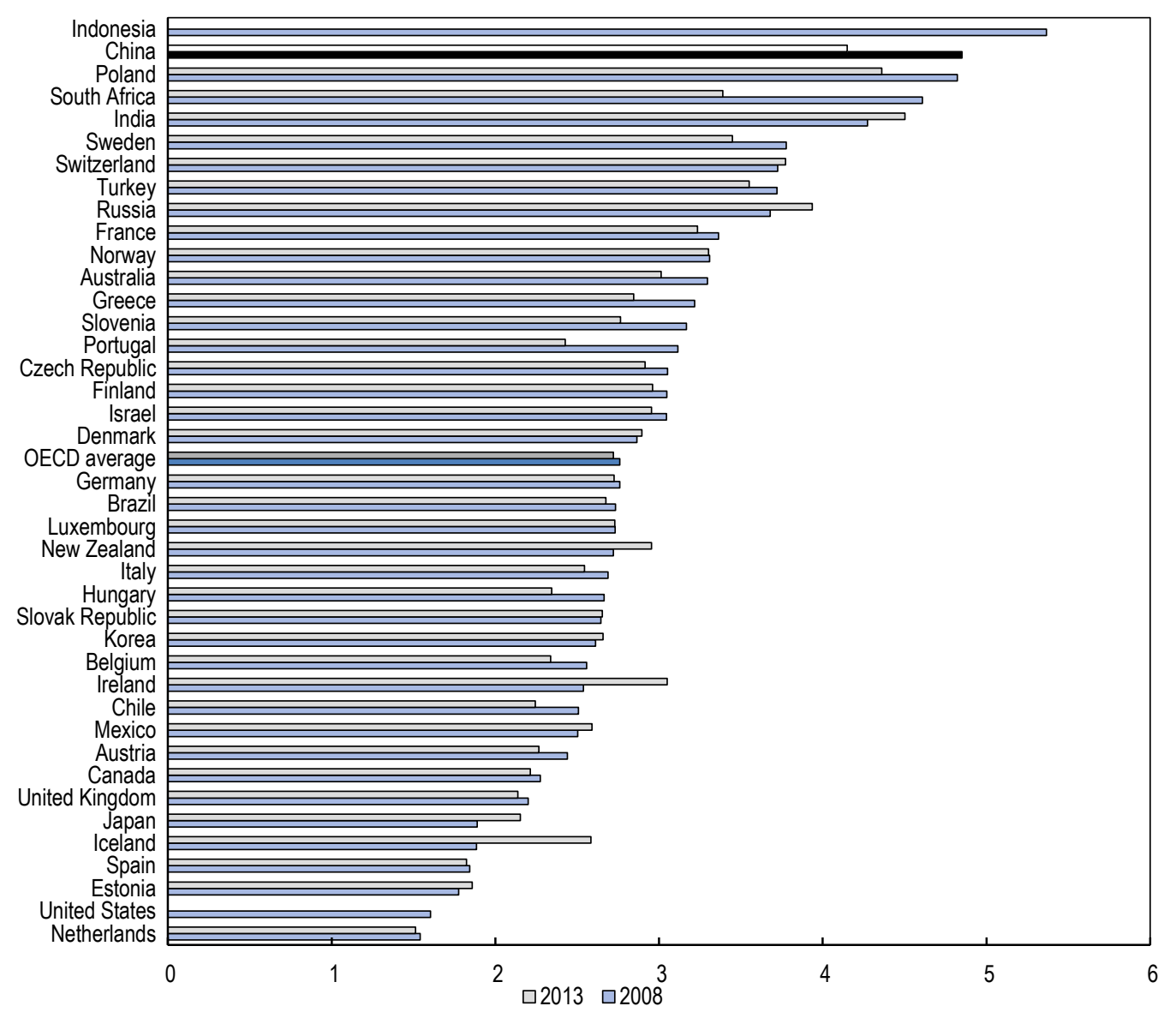

Note: The Product Market Regulatory indicator takes value between 0 and 6 with higher values indicating more stringent regulation. Countries are ranked by the 2008 indicator values. The reported 2013 indicators for Brazil, China, India, Mexico, Poland, the Russian Federation and Turkey are based on preliminary estimates as some of the underlying data has not been validated with national authorities. Subsequent data revisions may lead to revisions to the indicators for these countries.

Source: OECD Product Market Regulation database.

13. State-owned enterprises (SOEs) still dominate many service sectors, at least in terms of revenues, even in potentially competitive services like construction, and they have stakes in retail and hotel businesses (Figure 5). SOEs also command a high share of revenues in some business services such as management consulting and some professional services such as architecture and engineering. 
Figure 5. SOEs are dominant in a number of service sectors

Share of state-owned firms in the total number of firms, in revenue and in employment, 2008

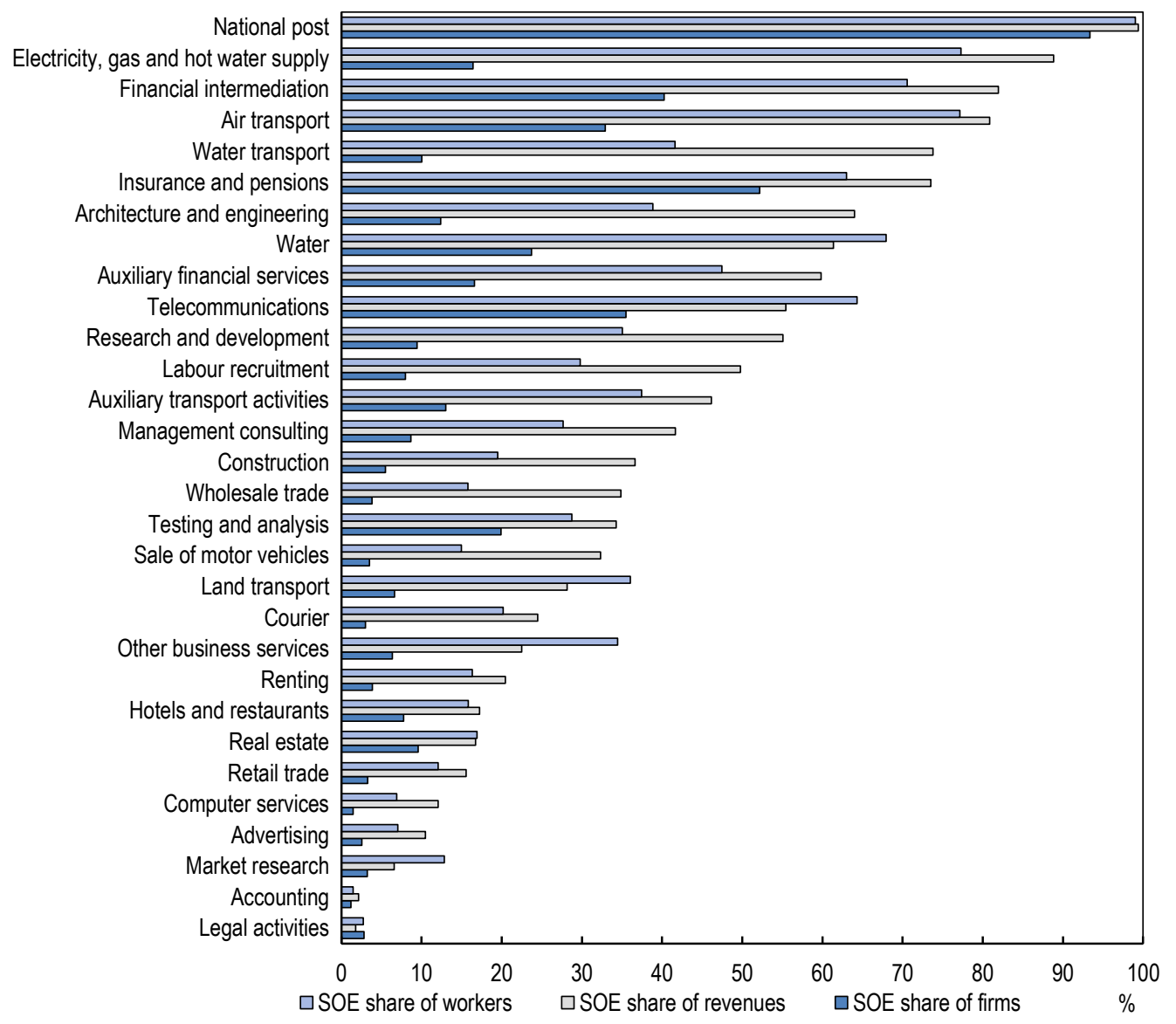

Note: Sectors are classified according to the United Nations ISIC Rev. 3 two-digit sector codes except for the following services, which are classified according to the four-digit sector codes: national post, courier services, legal activities, accounting and auditing, architecture and engineering, advertising, market research, labour recruitment, testing and analysis, and management consultancy. Sectors are ranked by the SOE share of revenues.

Source: Economic Census, 2008.

14. State ownership is even more common in network industries. In utilities such as electricity, gas and hot water supply as well as water, SOEs produce well over half of revenues and provide over $70 \%$ of employment. In air and water transport SOEs command over two-thirds of revenues and even in land transport nearly a third. Telecommunications, which is usually a liberalised sector with numerous private participants, is also dominated by SOEs in terms of revenues and employment.

15. SOEs in services tend to be large, their share among micro- or small firms (less than 20 and 2049 employees, respectively) is very low in terms of their number, revenue or employees (Figure 6.A). Among medium and large firms (with 50-249 and 250-999 employees, respectively), the SOE share is 20$30 \%$ in employment and the number of firms, and $40-60 \%$ in revenues. SOEs, however, command $40 \%$ of employment and around two-thirds of revenues in the very large category with employees above 1000 . This may be related to the sectoral distribution of SOEs: they tend to be strongly represented in utilities and transport industries that are generally larger. SOEs tend to be older than other firms; their share among the above-15-year-old firms is over two-thirds in terms of revenues and nearly half in terms of employment 
(Figure 6.B). A possible explanation is that in most traditional service industries such as transportation, construction and utilities, SOEs have long been dominant, while private sector participation has become possible and widespread in many industries only lately. In fact, apart from sales, hotels, catering and road transportation, most service industries had not been open to private or foreign entry until 2001. Moreover, many industries are still not fully open to private entry.

Figure 6. SOEs are dominant among larger or well-established firms and in several provinces

SOE shares of revenue, workers and firms, 2008

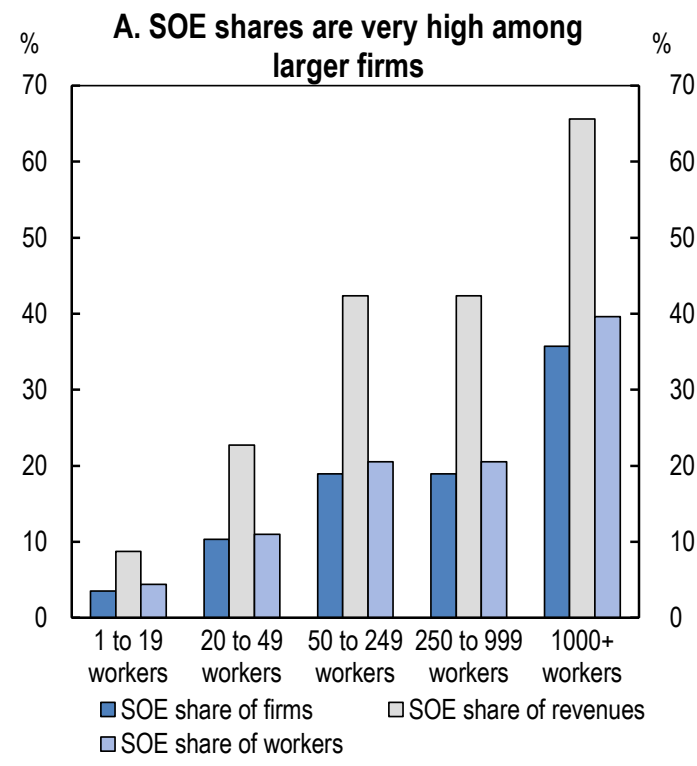

\section{B. SOE shares are very among well-}

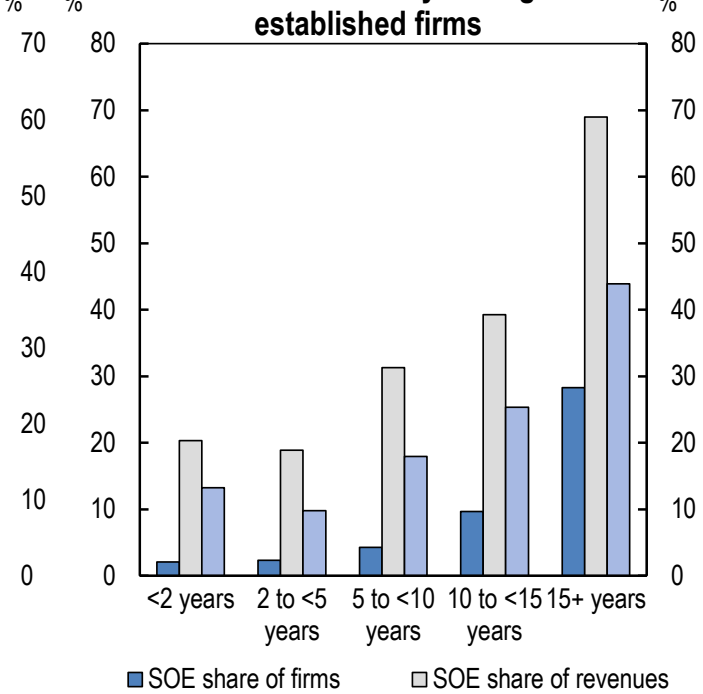

$\square$ SOE share of firms

$\square$ SOE share of revenues

$\square$ SOE share of workers

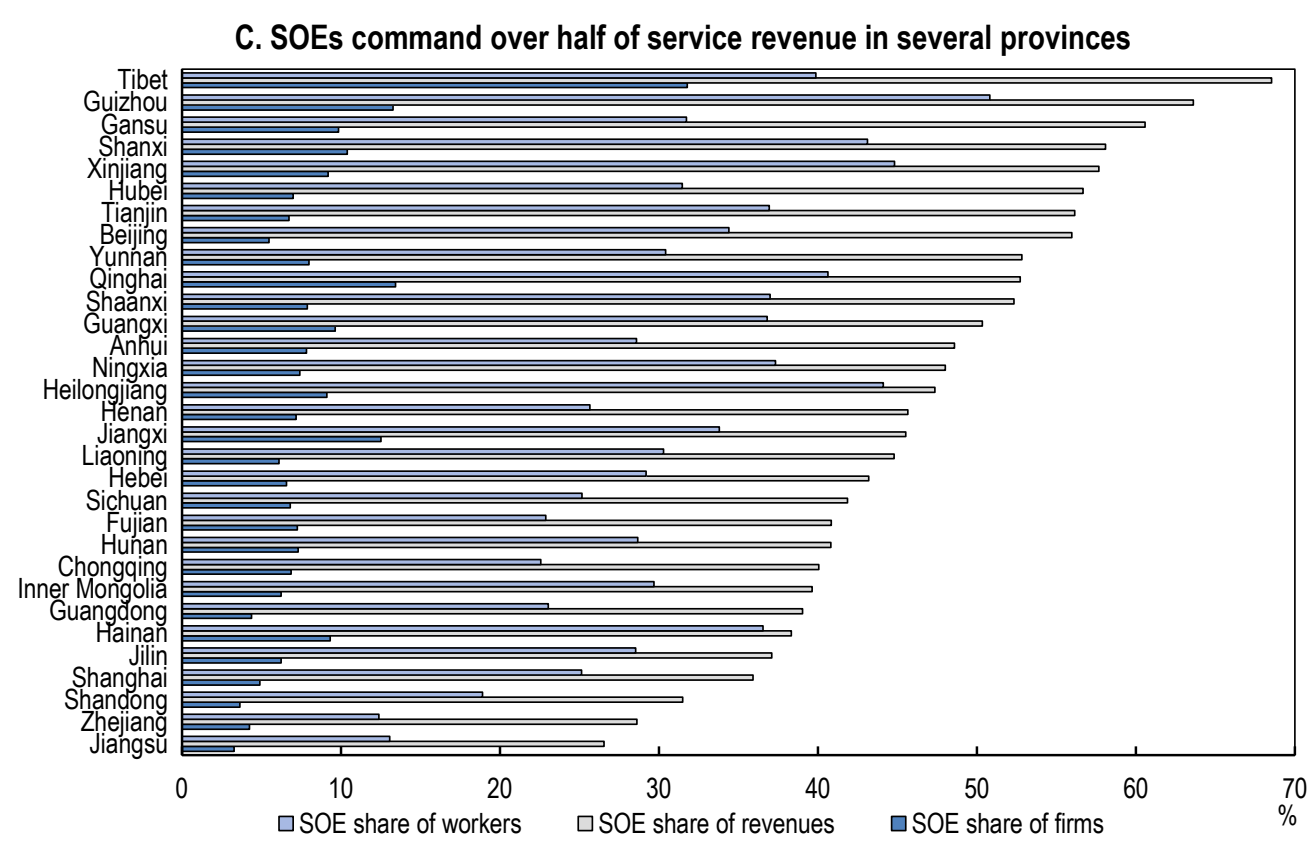

Note: SOEs are defined by the narrow definition of absolute or relative control by a state-owned enterprise. There are more stateinvested firms where the state is a non-controlling shareholder; those firms are not counted as SOEs.

Source: Authors' calculations based on the 2008 Economic Census. 
16. Somewhat surprisingly, SOEs command over half of service sector revenues and over a third of service sector employment in over a third of the provinces (Figure 6.C). Most of the provinces with very large SOE shares are in the West (Tibet, Guizhou, Gansu, Xinjiang, Qinghai, Shaanxi and Guangxi) but also in developed municipalities such as Beijing or Tianjin SOEs are dominant in services. In general, services are less developed and state ownership is more widespread in lower-income provinces. At the other extreme, Jiangsu, Zhejiang and Shandong have the lowest SOE shares in services. These provinces also happen to accommodate a larger share of overall firms (mainly manufacturing) than service firms and are the centres of private sector activity in China.

17. Kernel density estimates of productivity suggest that of the service sector SOEs, those owned by the central government are the most productive, alongside foreign-invested firms (Figure 7). Their density curves indicate that there are fewer low-productivity firms (shown by the lower humps) and more highproductivity ones (shown by the thicker tails) in those ownership categories. In contrast, collectivelyowned firms are the least productive, followed by SOEs belonging to local governments. Private firms are in the middle. In all ownership categories there are a few firms with very high productivity.

Figure 7. Central SOEs and foreign firms are most productive

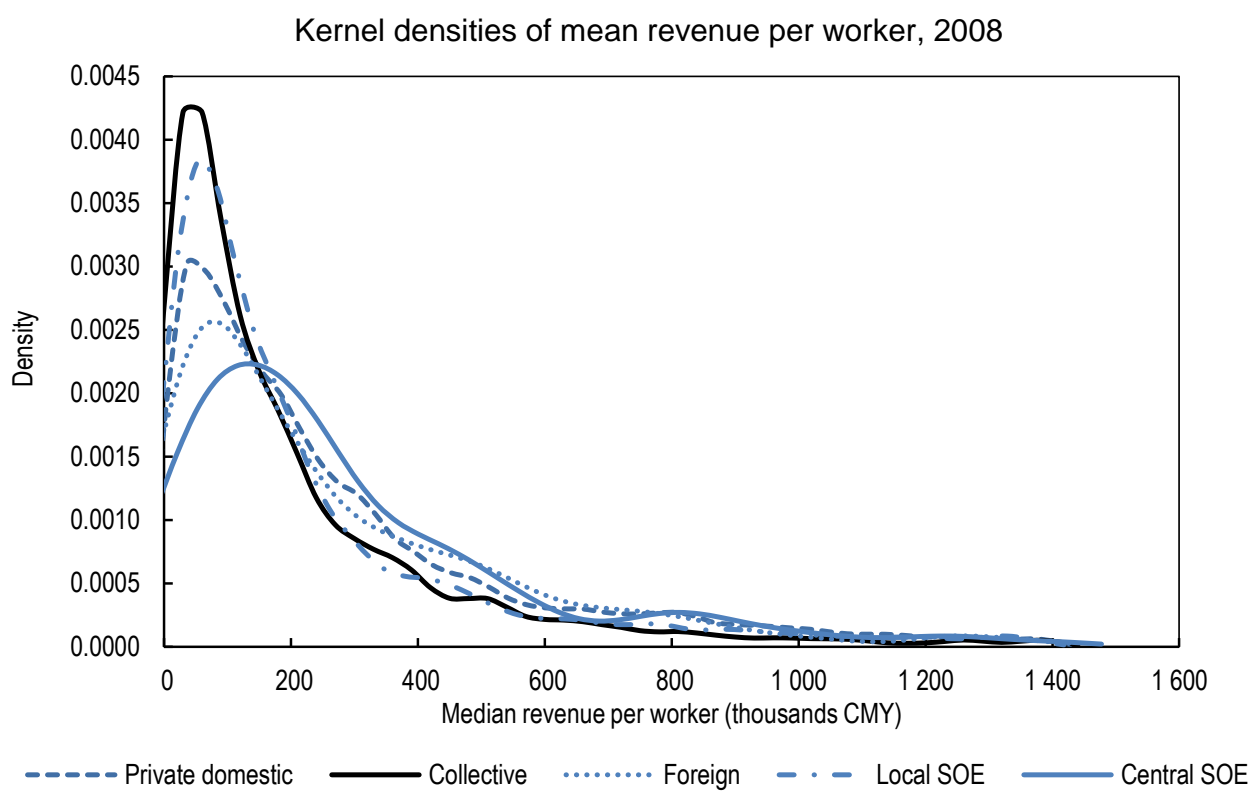

Note: Firms with zero revenue are included and the top $5 \%$ of the distribution is cut in the figure for visual clarity. Kernel density estimation is a non-parametric technique for plotting the distribution of the underlying continuous variable.

Source: Authors' calculations based on the 2008 Economic Census.

\section{Striking productivity differences across regions}

18. Inequalities in labour productivity across provinces measured by the Theil index are larger in services than in manufacturing industries. They are particularly large in electricity, gas and hot water supply, wholesale trade, water transport, financial services, telecommunications, real estate, $R \& D$ and some business services such as management consulting, advertising and labour recruitment - all with a value of 0.8 or above (Figure 8.A). At the other extreme, inequalities in labour productivity are the smallest in the hotel and restaurants business with a Theil index value around 0.4 , lower than in any manufacturing industry. This partly reflects the more standardised nature of those services. Productivity inequalities are also low at 0.5 in legal services, which is somewhat surprising as legal services are highly customised by nature, though price regulations, widespread in professional services, may provide an explanation. 
19. When decomposing labour productivity inequalities into a within and a between-province component, the former explains most of the variation (Figure 8A). This may reflect that in all provinces there are both high-and low-productivity firms, which in turn may be related to the urban-rural divide. In some sectors, however, at least a fifth of differences are explained by between-province variation such as in electricity, gas and hot water supply, water transport, air transport and national posts. These differences can be related to endowments, economic development and universal service obligations. Energy-rich provinces or those with natural waterways such as the Yangtze or the Yellow River are likely to achieve higher productivity in energy-related industries or water transport, respectively. Air transportation tends to be more concentrated in developed regions, implying potentially higher productivity. Furthermore, the postal service is subject to universal service obligations; therefore in sparsely populated areas productivity may be lower. Among different firm sizes, very large firms (above 1000 workers) tend to have the smallest disparities in productivity. Most productivity differences are explained by the within-province component. Productivity disparities among all age groups are very large, with the youngest firms having the smallest. As in the case of sectors and firm sizes, here also the within-province dimension is dominant in driving disparities. 
Figure 8. Geographical productivity differences are driven by within-province disparities

Theil index of firm-level productivity inequalities across provinces by industry, size and age, 2008
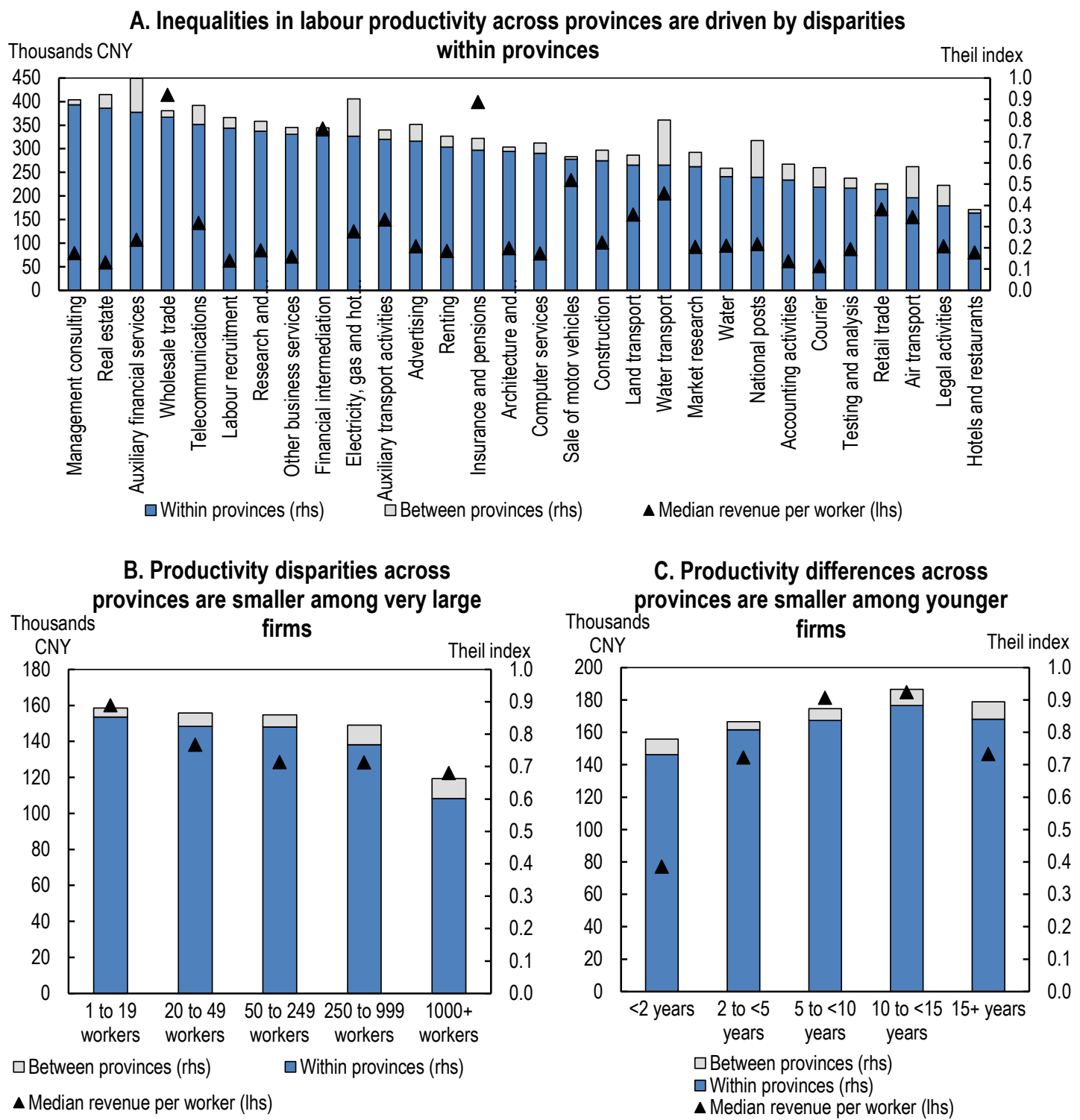

Source: Authors' calculations based on the 2008 Economic Census.

20. Inequalities in labour productivity were also decomposed into a within- and across-county component to get a potential insight into urban-rural productivity gaps. As all provinces have highly urbanised and very rural areas, the between-province decomposition would not shed light on the urbanrural divide. Counties, however, are more specialised and many are rural. Labour productivity inequalities across counties are large in the same industries where inequalities across provinces are high. At the county level, however, the between-county component of the decomposed Theil index explained a greater part of inequalities (Figure 9.A). The patterns across firm sizes and ages are also similar to the province-level inequalities, except that at the county level, the between component tends to be larger (Figure 9.B and C). So for the productivity of a firm, the county where it is located appears to matter more than the province. This may be related to the urban-rural divide, in particular in services. Interestingly, this does not happen to be the case for manufacturing firms, for which the between-county component is small. When looking at 
the decomposition of cross-county productivity differences into a within and between-county component in each province, it appears that in most provinces the within component is dominant, but in a few Western provinces such as Xinjiang, Qinghai and Inner Mongolia as well as Hainan, the between-county component is larger than in other provinces (Figure 9.D). Those three Western provinces are very large and sparsely populated with large remote rural areas in each. This may exacerbate productivity disparities across counties even within the same provinces. 
Figure 9. Productivity differences at county level are also driven by between-county differences

Theil index of firm-level productivity inequalities by industry, size, age and province

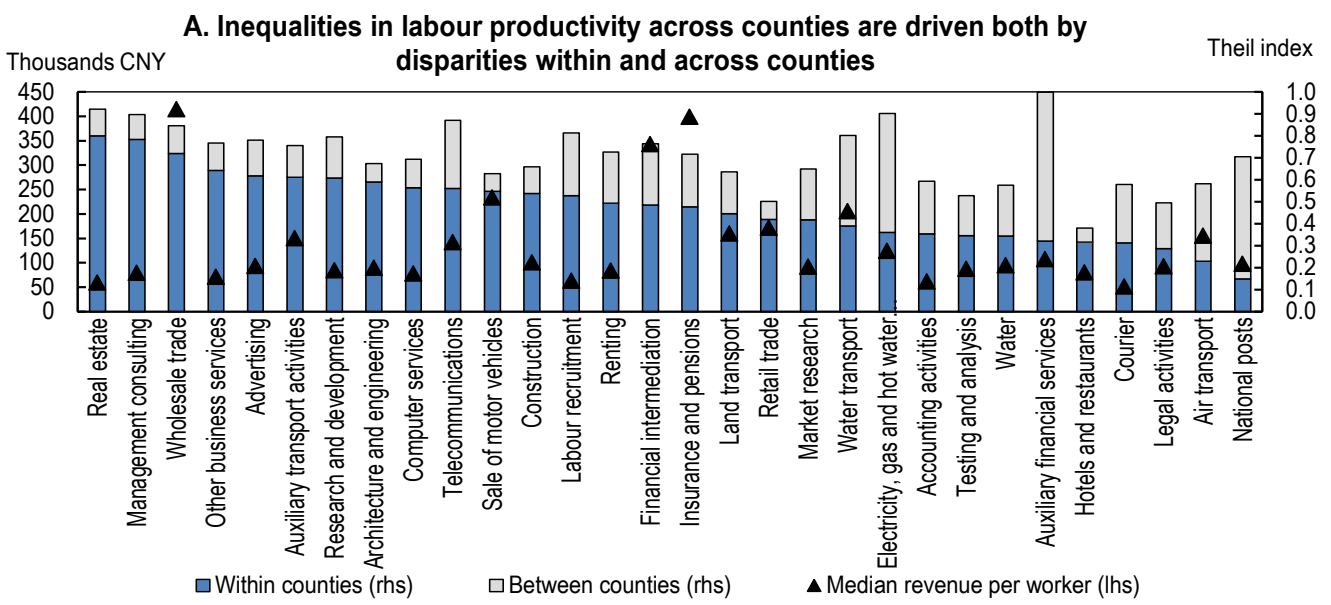

B. Productivity differences across
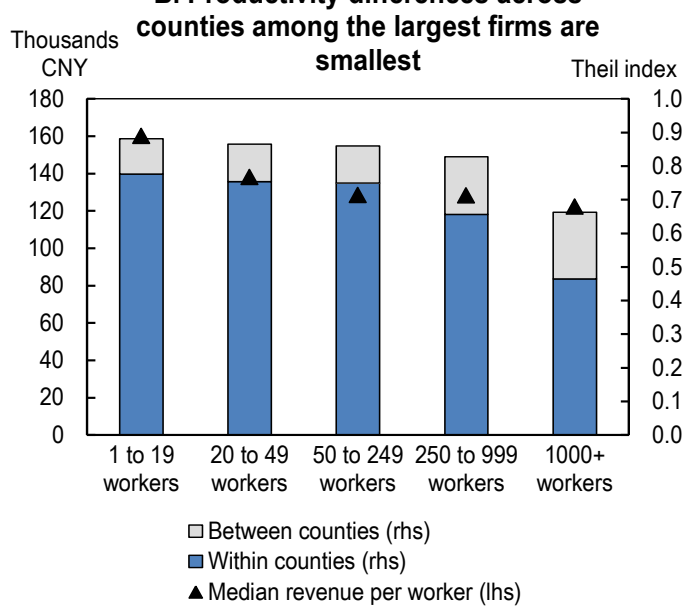

C. Productivity differences across counties are smaller among younger
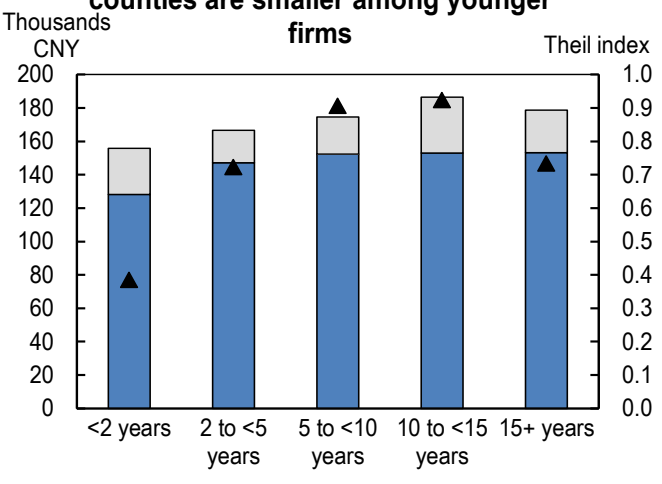

$\square$ Between counties (rhs)

$\square$ Within counties (rhs)

$\Delta$ Median revenue per worker (lhs)

D. In most provinces productivity differences across counties are driven by

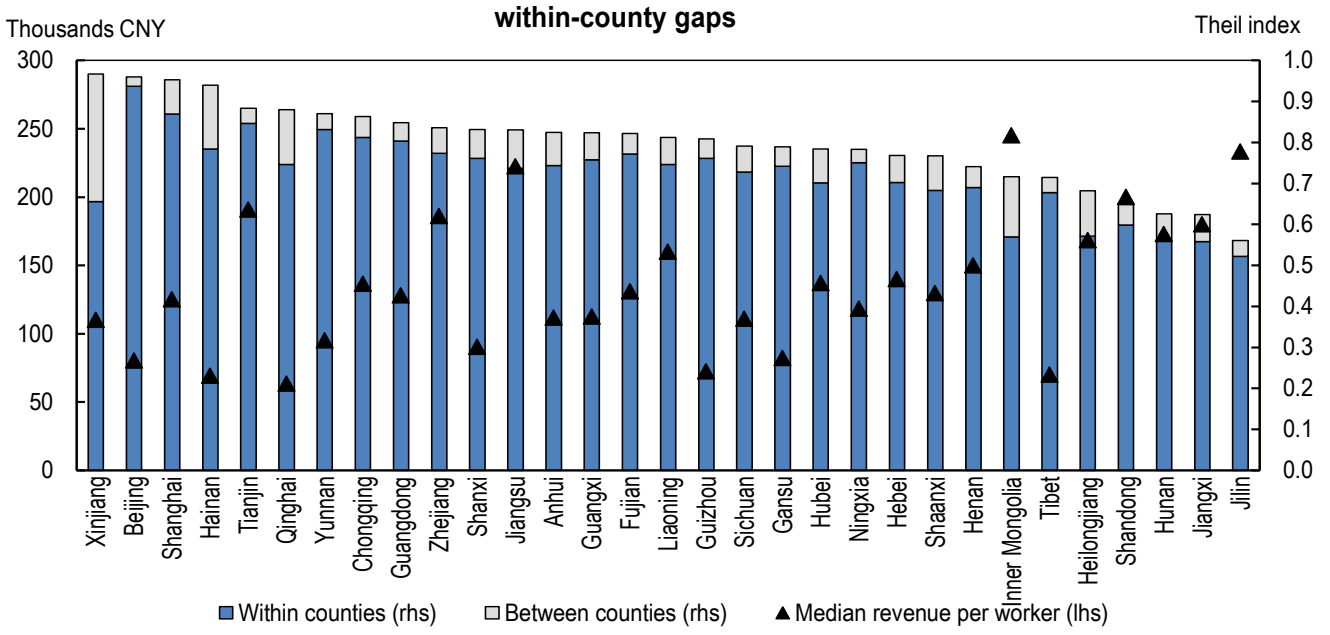

Source: Authors' calculations based on the 2008 Economic Census. 


\section{Regulations and productivity patterns vary widely across service industries}

21. Productivity performance and patterns vary widely across industries, likely reflecting regulatory settings. The extent to which market forces are at work and create healthy competition among producers for the satisfaction of consumers differs greatly across service sectors. In well-functioning markets, firms are motivated to produce at the lowest possible cost and consumer satisfaction cannot be improved by reallocating resources. In such circumstances, the government's role is to provide frameworks in which market forces operate. Markets, however, may fail to allocate resources efficiently in the case of, for instance, excessive market power, public goods or externalities, which warrant government intervention. If not correcting for market failure, government intervention can be costly in terms of direct internal costs related to the resources the government spends on the intervention, direct external costs in the form of higher production costs and indirect costs stemming from potential externalities, inefficiencies and disincentives created by the intervention. To economise on the costs of intervention, regulation needs to be strengthened to create the right incentives both to produce at the lowest possible cost and to achieve maximum consumer satisfaction. In China, like in many other countries, there are numerous cases of overor under-regulation and the extent of competition/industry structures varies from monopolies/oligopolies with one or a few competitors in some markets to unfettered competition among scattered producers in others.

22. Network industries have high entry barriers and in China their prices are heavily regulated. Introducing competition into, for instance, the energy sector and shifting towards retail prices that reflect actual costs of generating, transmitting and distributing electricity and incorporate the environmental costs of carbon-generated energy are key ways to enhance efficiency. Greater competition, however, would squeeze incumbents' profit margins and more market-based pricing would raise costs for beneficiaries of cheap energy.

23. Conversely, competition is fierce in some services such as retail or land transportation. Instead of gaining advantage by innovating, many producers engage in cut-throat price competition endangering product quality and safety. This race to the bottom often leads to counterfeiting and ignoring product safety regulations. Establishment and enforcement of standards alongside raising consumer awareness and enhancing consumer protection would help promote fair competition. In new industries, such as auctioning, the lack of regulation or its enforcement has led to abuse. Auctioning fees are calculated as a percentage of the estimated value of the good to be auctioned, with the estimation done by the auction house and the fee retained even if the commissioned good fails to be sold.

\section{Logistics and transport services are in general relatively competitive}

24. The logistics and transport sector is characterised by an oligopolistic market structure in restricted industries and intense competition in less restricted ones such as trucking, general logistics and express delivery. The major engine of logistics and transportation services has been e-commerce. As developing in-house logistics entails high costs for retailers, the majority (61\%) opt for using third-party services.

25. A crucial ingredient of productivity is efficient supply chain management. Companies with lower logistics costs within a sector appear to have fewer suppliers. However, most firms pick the lowest-cost supplier for each particular route or logistics activity (A.T. Kearney, 2009). Arguably, having more stable customer relations would nurture trust and reduce costs. Most firms (86\%) appear to track on-time delivery performance, but not all of those link it to their reward system (only $51 \%$ of the total). The quality of logistics and transportation services in general is judged as mediocre by users (PWC, 2011). 


\section{Road transport}

26. The trucking business belongs to the competitive types of services, with nearly 50000 firms employing nearly two million people. The sector is very fragmented, with a median number of employees of only five in Beijing, for instance. Disorderly competition is an issue in the trucking business, where truck drivers regularly ignore red lights at night as they are under pressure to deliver as much and as fast as possible, thereby causing accidents. They also tend to carry excessive load to economise on road tolls that are relatively high. The 2008 creation of the Ministry of Transport by merging the Ministry of Communications, the Civil Aviation Administration and the State Postal Bureau in a single entity reduced regulatory overlap, making the regulatory framework more efficient. Notwithstanding cut-throat price competition among the tens of thousands of businesses of all sizes, heavy road tolls accounting for 30-40\% of total costs make transportation expensive (Zito, 2014). Also, licensing requirements restrict entry to the trucking business (Figure 10) more than in other countries. Inefficiencies also arise from local restrictions on who is allowed to pick up loads, leading to no-load trucks in $37 \%$ of journeys (KPMG, 2011). Fair competition can be stimulated by a more stringent enforcement of truck standards and weight limits and the requirement of a trucking licence.

Figure 10. Entry to the road transportation business is highly restricted

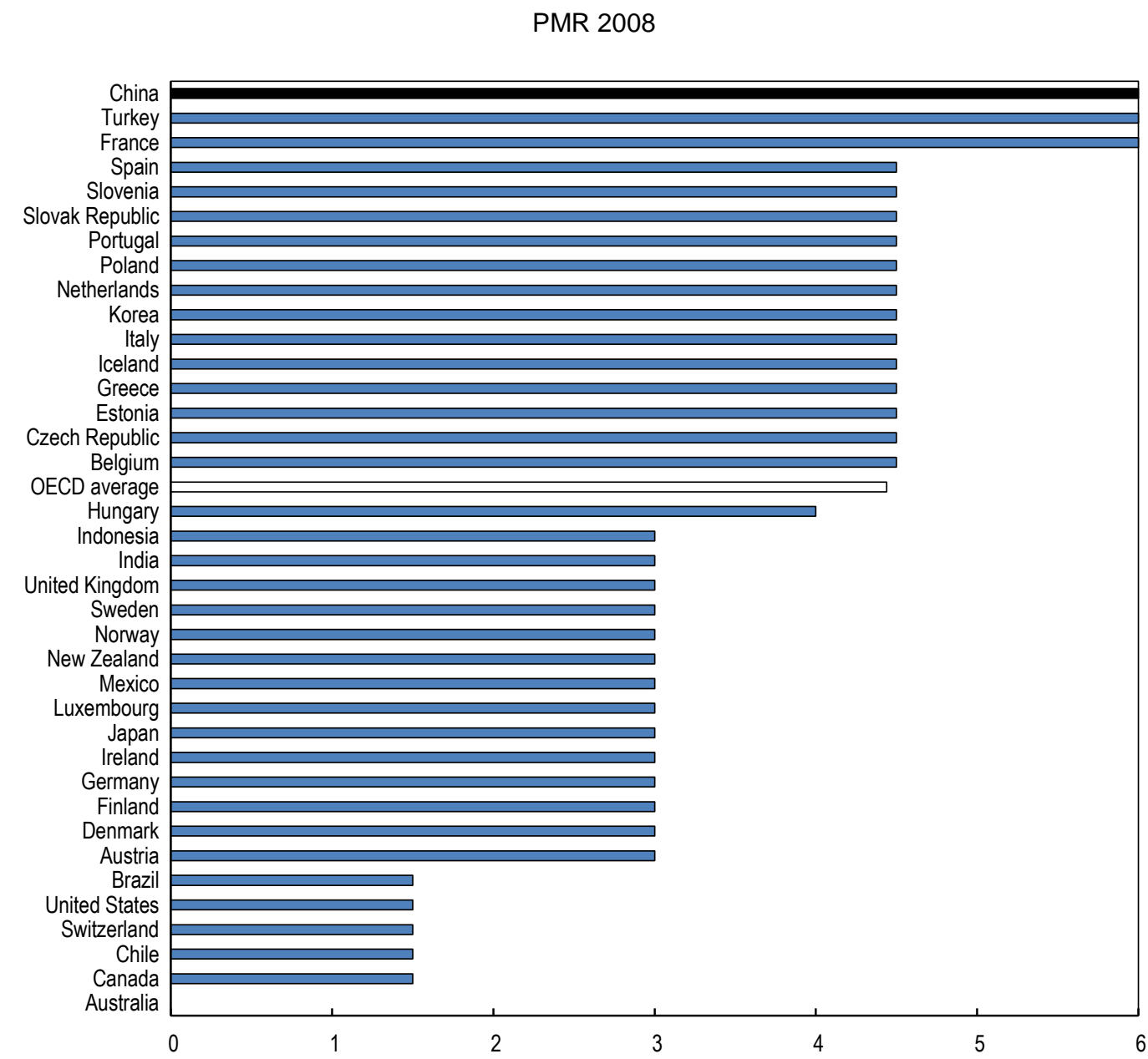

Note: The Product Market Regulatory indicator takes value between 0 and 6 with higher values indicating more stringent regulation.

Source: OECD Product Market Regulation database. 
27. Productivity in road transportation increases with firm size up to a medium range (50-249 employees) (Figure 11.A) and then decreases for larger firms. Most firms, however, as mentioned above, are in the micro category with fewer than 20 workers and produce a small share of revenues. Trucking firms between two and 15 years old appear to have similar revenues per worker, though there are few firms above 10 years (Figure 11.B). Younger trucking companies may be less productive as they lack a wellestablished customer base and reputation, while the low productivity of the older ones may be related to older trucks and thus low-pay jobs. There is about a ten-fold difference between the productivity levels of firms in Tianjin and Xinjiang, the two extremes in the province/municipality ranking (Figure 11.C).

Figure 11. Two- to 15-year old firms are most productive, while size does not appear to matter for productivity Median revenue per worker by firm size, age and province

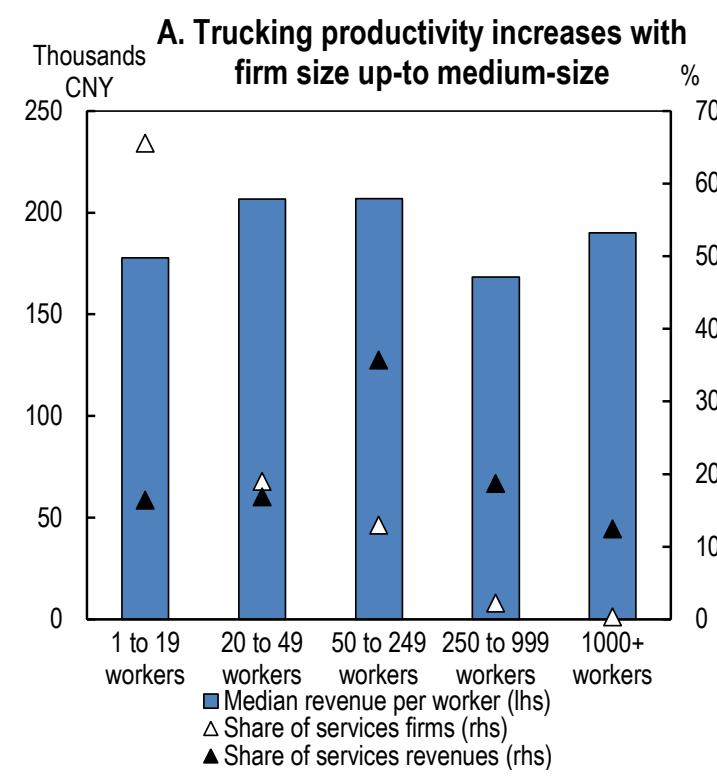

B. 2-14 years old trucking companies are

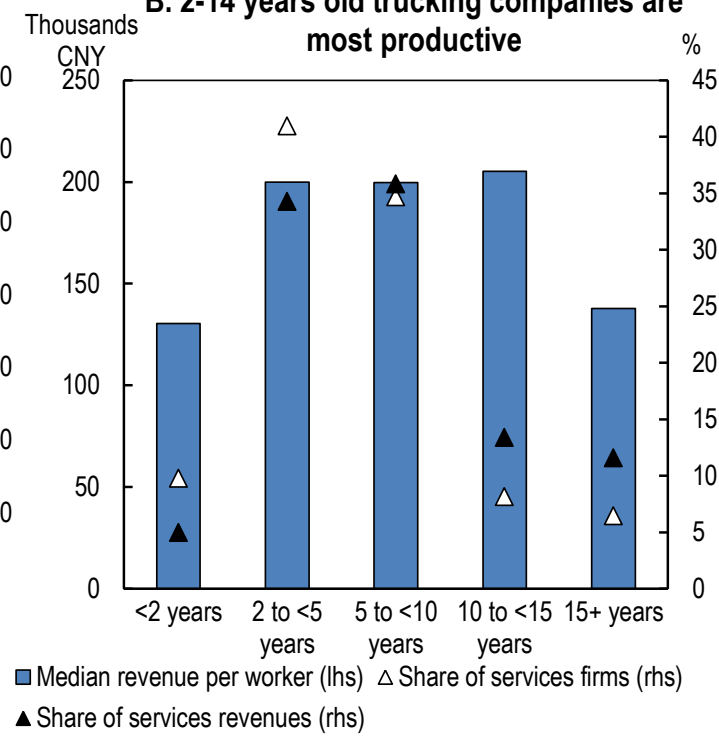

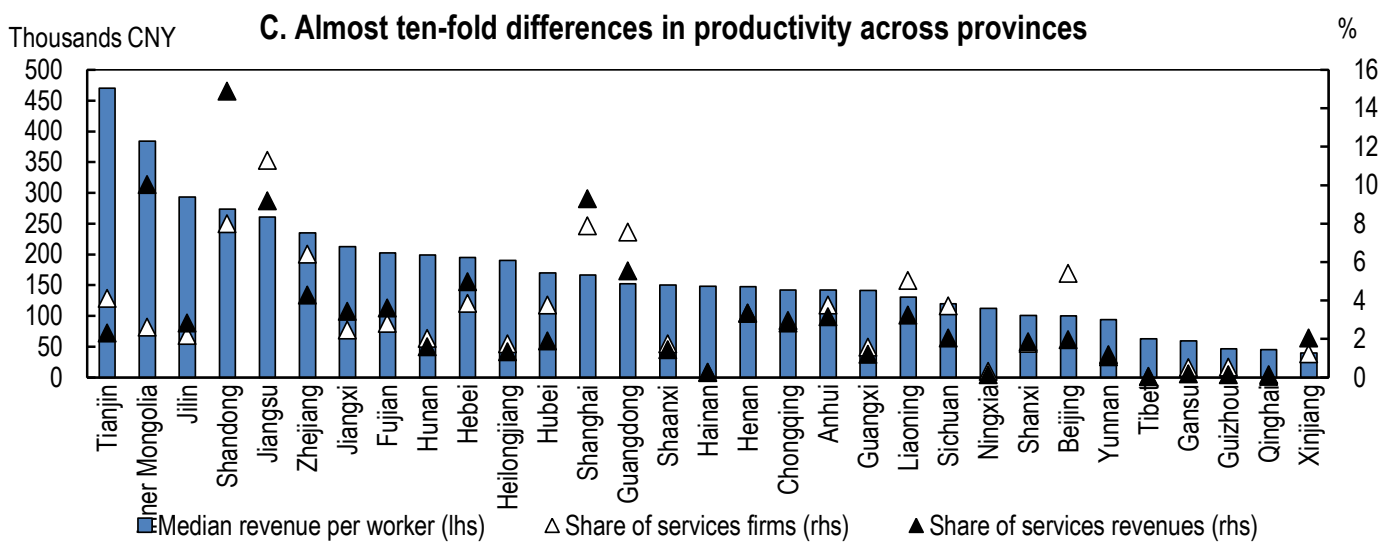

Note: Road transportation includes firms in category 6023 under the United Nations ISIC Rev. 3 classification. Source: Authors' calculations based on the 2008 Economic Census.

\section{Express delivery}

28. With the proliferation of online purchases, the courier business has been expanding rapidly. In 2008, there were over 3700 express delivery firms in China and their number more than doubled in the 
following five years. The history of express delivery goes back to the early 1980s when the China Post Administration started its express mail service (Deloitte and Development and Research Centre of the State Post Bureau, 2014). A few years later, a few foreign express delivery firms were allowed to set up joint ventures with Sinotrans Group for international express delivery in China. From 1993, private companies entered the market gradually, focusing on delivery of business documents and small parcels for a smaller fee than their giant state-owned competitor. Before online purchase was possible, in 2008, express delivery companies started to collect payment at delivery. The courier business developed first in regions where the private sector is most flourishing: the Yangtze River Delta, the Pearl River Delta and the Beijing-TianjinHebei Corridor. This spatial aggregation pattern has remained until recently.

29. According to the OECD Services Trade Restrictiveness Index (STRI)(Nordas and Rouzet, 2015), courier services face very high restrictions, in particular with respect to foreign entry, and there are also barriers to competition (Figure 12) (Geloso Grosso et al., 2014b). Indeed, it was not until the mid-2000s that foreign companies could establish fully-owned subsidiaries and did not have to partner with domestic companies to engage in express delivery services. In early 2015, three foreign firms were licensed to provide courier services in China. The licensing procedure, however, remains cumbersome as providers need to apply for one license per city and are allowed to deliver only in cities they have a license for.

Figure 12. Foreign entry and competition are restricted in courier services

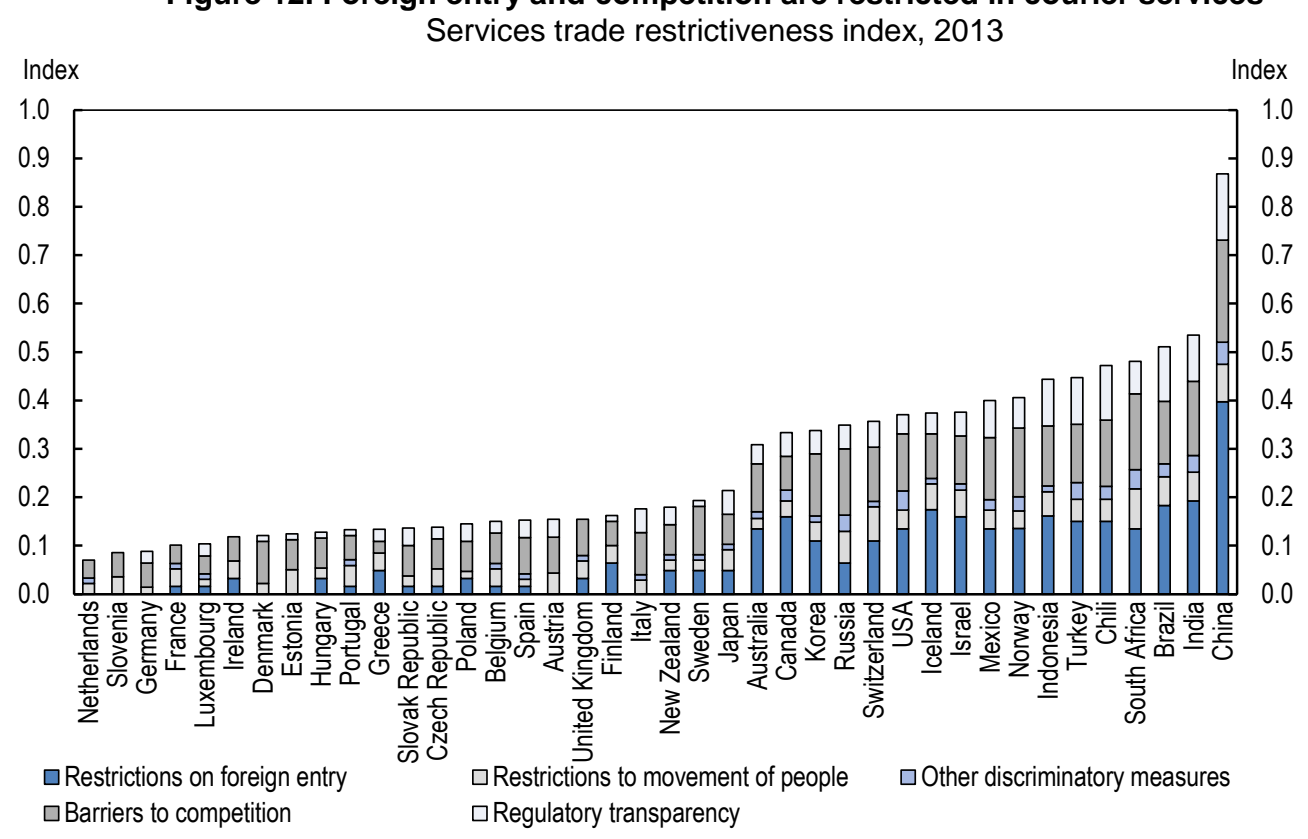

Note: The Services Trade Restrictiveness Index takes values between 0 and 1, with higher values indicating more stringent regulations.

Source: OECD Services Trade Restrictiveness Index database.

30. In the courier business micro enterprises are the least productive, though their share is the largest (Figure 13.A). The oldest firms above 15 years are much more productive than younger ones (Figure 13.B). This may reflect the fact that it may take time to establish reputation by an express delivery company and that some of the oldest companies are state owned and specialise in higher value-added segments. Indeed, private companies in the sector compete on price: in 2013 they produced $79 \%$ of volume but only $68 \%$ of income in the business (Deloitte and Development and Research Centre of the State Post Bureau, 2014). Furthermore, there is specialisation by ownership: foreign firms command over half of the revenues in the international delivery segment, the most profitable one, while they are absent from the intra-city delivery segment and command a very small share of the inter-city delivery market. Private firms 
dominate both the intra- and inter-city delivery markets. Productivity in courier services is about nine times higher in Shandong than in Tibet (Figure 13.C).

Figure 13. Experience and location matters most for express delivery productivity

Median revenue per worker by firm size, age and province
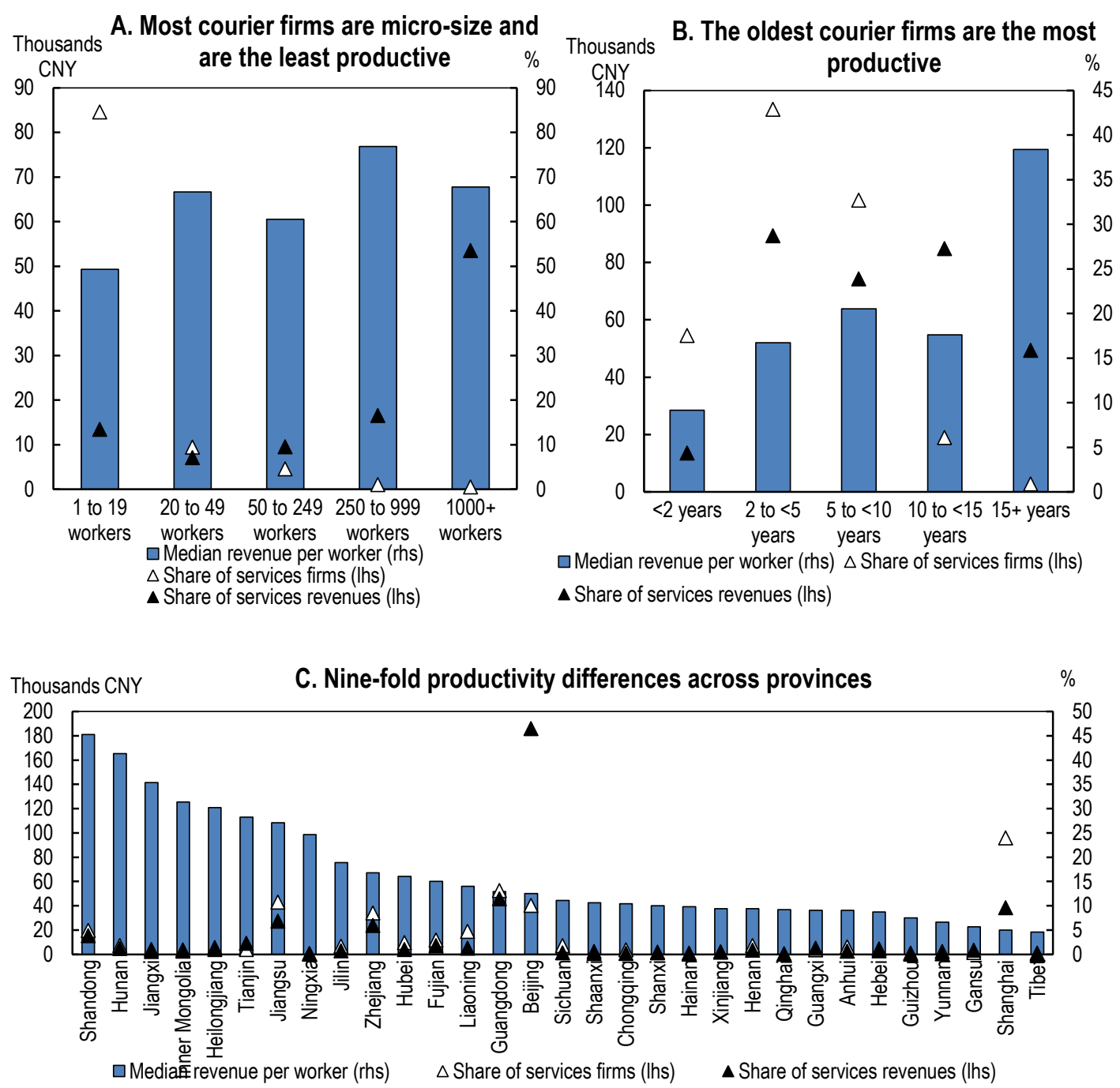

Note: Express delivery includes firms in category 6412 under the United Nations ISIC Rev. 3 classification.

Source: Authors' calculations based on the 2008 Economic Census.

\section{Distribution services are relatively competitive}

31. The retail distribution sector is a relatively liberalised and competitive one with all ownership types represented. Foreign competitors, either wholly owned subsidiaries or joint ventures have an advantage in management skills and innovation, while SOEs often own their stores, allowing them to economise on rental fees that have been squeezing retailers' profits in recent years. Large real estate investments, however, may lock up company funds and prevent firms from investing in new technology, adopting new management practices or spending on other productivity-enhancing measures. 
32. Although retail distribution is subject to relatively few regulations, and entry barriers are relatively low compared to other industries in China, in international comparison, licensing requirements are high (Figure 14).

Figure 14. Licensing requirements to operate retail outlets are high

Licences and permits needed to engage in commercial activity, 2008

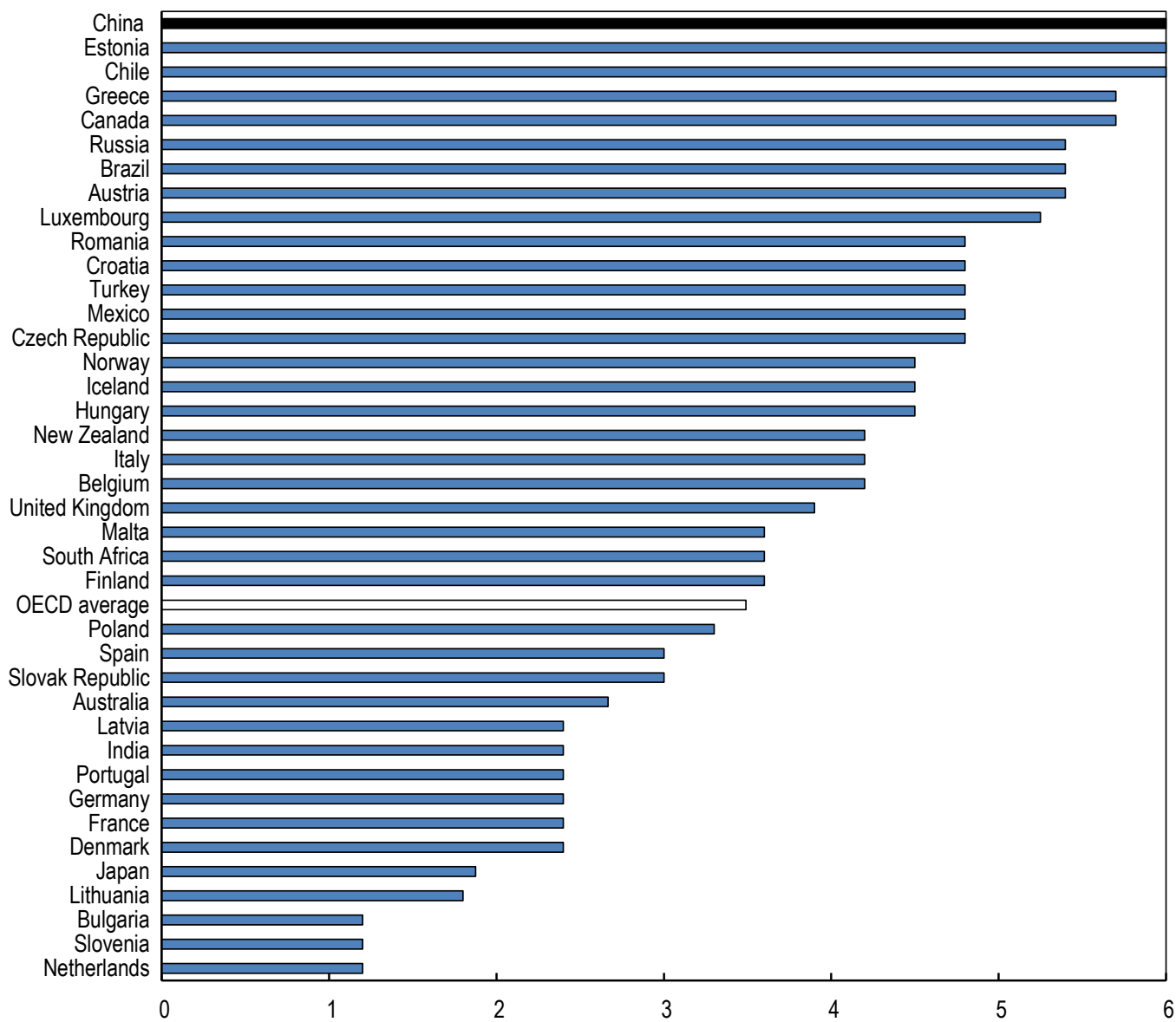

Note: The Product market regulatory indicator takes values between 0 and 6 with higher values indicating more stringent regulation.

Source: OECD Product Market Regulation database.

33. Looking into the years to come, prospects for the distribution industry are bright. Policies fostering development in Western regions are expected to boost the distribution business as improved infrastructure opens up new markets for retailers. Increased competition is likely to drive further mergers in the sector (Wang, 2013).

34. The retail sector is very diverse; productivity therefore is examined by retail store type (groceries and supermarkets, general and department stores, specialised food stores, pharmaceuticals and cosmetics, clothing, household appliances, hardware, paint and glass, mail order, stalls and markets and non-store retail). Some common patterns emerge. Scale matters a lot for retail outlet productivity: for most store types (except non-store retail, stalls and market, mail order and specialised hardware, paint and glass retailing) the largest ones are the most productive. But the majority - at least $70 \%$ - of all store types employ fewer than 20 people. Very young (below two years) and older (above 15 years) stores appear to be less productive. 
35. Productivity patterns by ownership vary a lot by type of retail outlet. Among groceries and supermarkets as well as in general and department stores, foreign-controlled ones display a significant productivity lead (Figure 15). Foreign firms mainly operate supermarkets or hypermarkets and their technology and management advantage results in more productive retailing. In some specialised stores such as pharmaceuticals and cosmetics, household appliances and hardware, paints and glass, central SOEs are the most productive. Higher productivity may sometimes be explained by establishing retail outlets by manufacturers such as in the case of some state-owned electronics makers at the central level. The private sector is productivity leader among all ownership types in the category of retailing through stalls and markets, though in this segment there are no foreign or central SOE competitors. Collectively-owned retail outlets followed by locally-owned SOEs are the least productive in nearly all retailing categories. Mail order is an exception with fewer collective firms or local SOEs among the least productive firms.

\section{Figure 15. Foreign-invested groceries and supermarkets are the most productive}

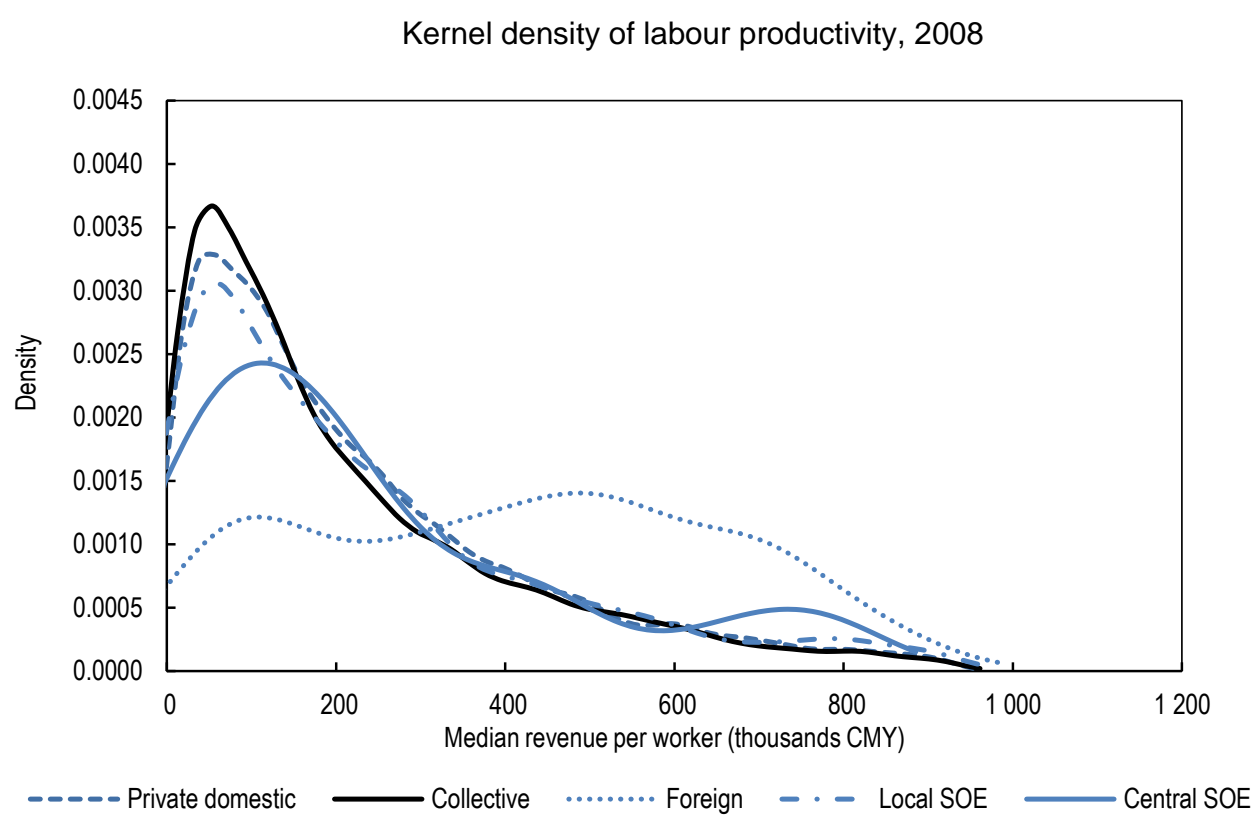

Note: Grocery stores include firms in category 5211 under the United Nations ISIC Rev. 3 classification. Firms with zero revenues are included and the top $5 \%$ of the distribution is cut in the figure for clearer visibility. Kernel density estimation is a non-parametric technique for plotting the distribution of the underlying continuous variable.

Source: Authors' calculations based on the 2008 Economic Census.

36. For grocery stores, size matters a lot. Stores with at least 250 workers can be twice as productive as smaller stores (Figure 16.A). New stores do not appear to be very productive, but neither do the ones older than 15 years (Figure 16.B). Surprisingly, the biggest cities such as Shanghai and Beijing have the least productive firms in the grocery sector (Figure 16.C). This may be explained by the large number of small stores they have. 
Figure 16 . Size matters most for grocery store productivity

Median revenue per worker by firm size, age and province
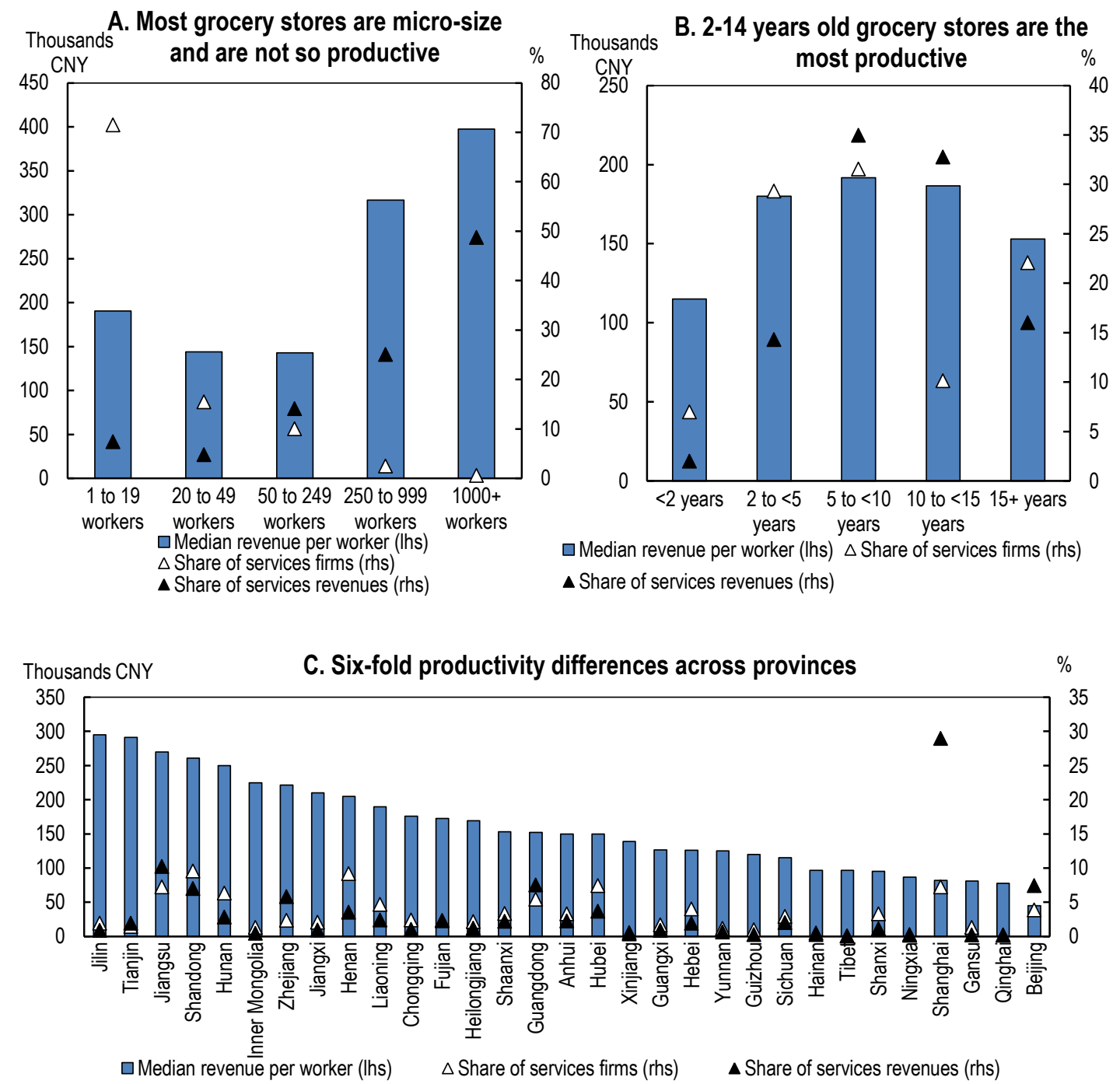

Note: Grocery stores include firms in category 5211 under the United Nations ISIC Rev. 3 classification.

Source: Authors' calculations based on the 2008 Economic Census. 
Figure 17. Department store productivity appears to increase with size

Median revenue per worker by firm size, age and province
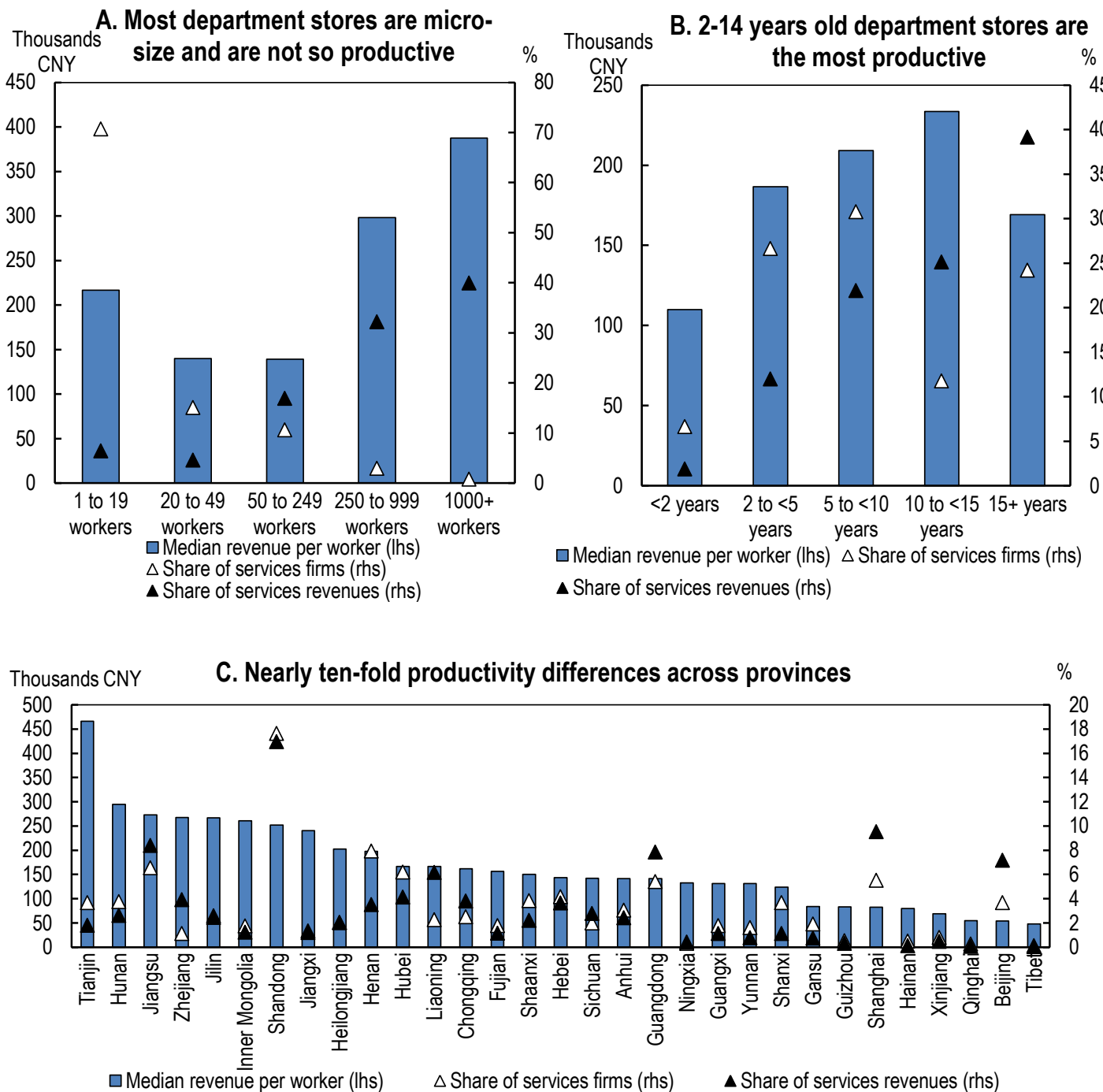

B. 2-14 years old department stores are Thousands CNY the most productive
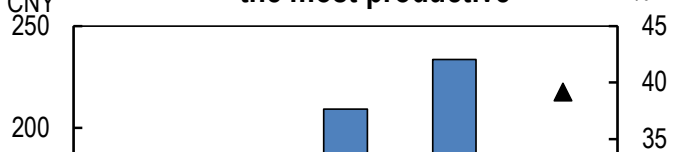

(1)

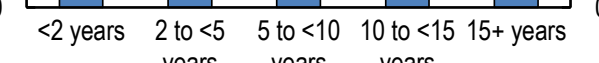
$\square$ Median revenue per worker (lhs) $\triangle$ Share of services firms (rhs) Share of services revenues (rhs)

Note: Department stores include firms in category 5219 under the United Nations ISIC Rev. 3 classification.

Source: Authors' calculations based on the 2008 Economic Census.

\section{Professional services are subject to a number of restrictions}

37. State involvement in various aspects of operations of professional service businesses appears widespread and takes the form inter alia of price controls (Figure 18) and command and control regulation. Most professional service providers such as accountants, architects, engineers and legal service providers are subject to more stringent controls of prices and fees than providers in OECD member countries. 
Figure 18. Price controls are widespread in China

Product market regulation indicator, 2013

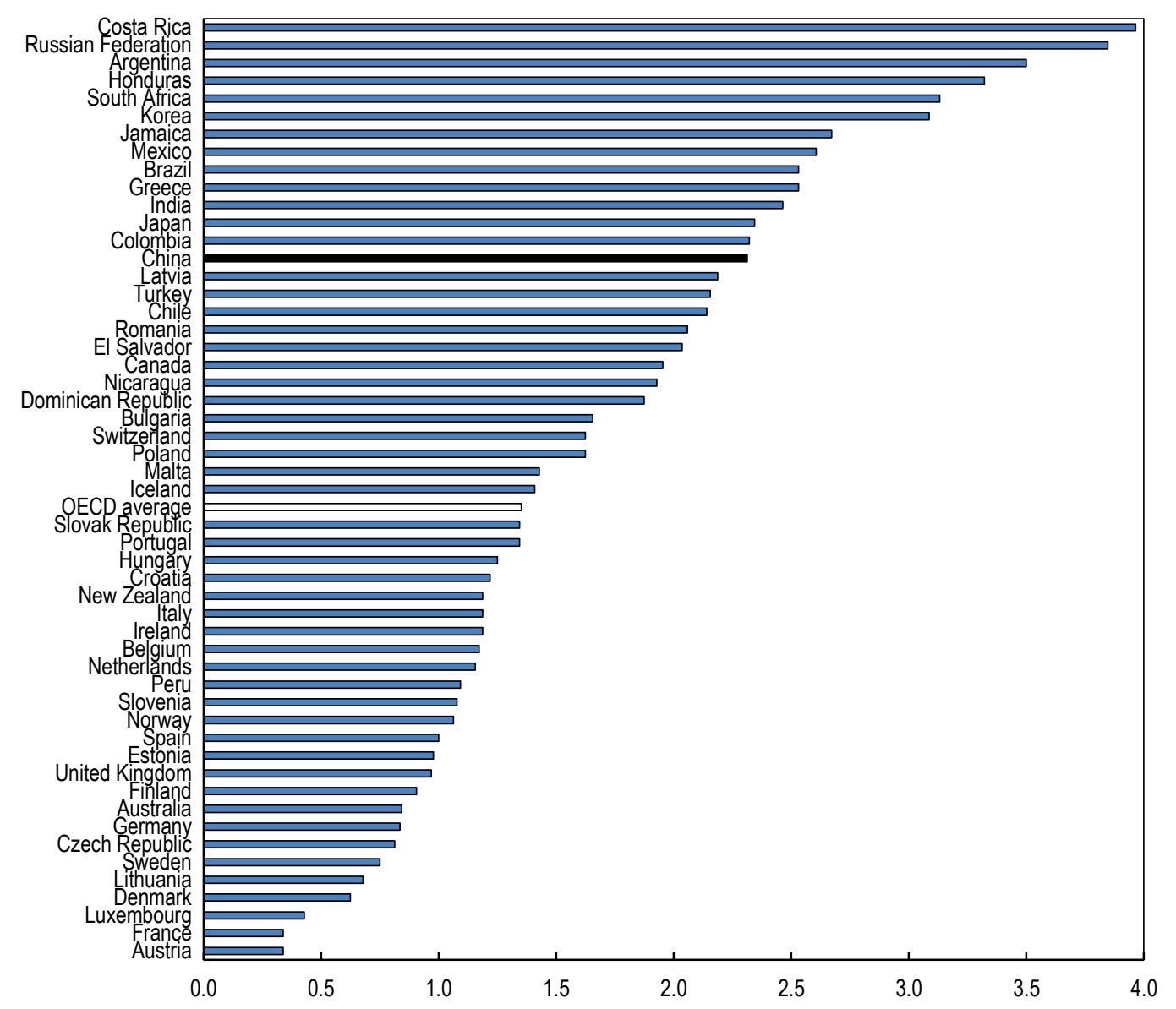

Note: The PMR sub-indicator of price controls reflects the extent and type of price controls in eight sectors. The values of the indicator range between 0 and 6 , with higher values indicating more stringent regulation. The reported indicators for Brazil, China, India, Mexico, Poland, the Russian Federation and Turkey are based on preliminary estimates as some of the underlying data has not been validated with national authorities. Subsequent data revisions may lead to revisions to the indicators for these countries.

Source: OECD (2013) Product Market Regulation Database.

38. The State does not only excessively control prices, but also, to a great extent, it uses administrative - as opposed to incentive-based - regulation (Figure 19). Advertising is strictly controlled in architecture and engineering services. Advertising is sometimes prohibited on the grounds that it distorts consumer choice in conditions where consumers have difficulties in selecting a provider owing to the specific nature of professional services. Evidence, however, shows that restrictions on advertising increase the fees charged for professional services. Restrictions on advertising have been lifted for a few services in some OECD countries. Partnerships, associations and joint ventures with other professions are not allowed in accounting, engineering and architecture services, which may limit synergies stemming from bundling of services. To make regulation more efficient, in many countries regulators are required to assess alternative policy instruments (regulatory and non-regulatory) before adopting new regulation. 
ECO/WKP(2015)35

Figure 19. Command-type regulation is more common in China than in many OECD countries

Product market regulation indicator, 2013

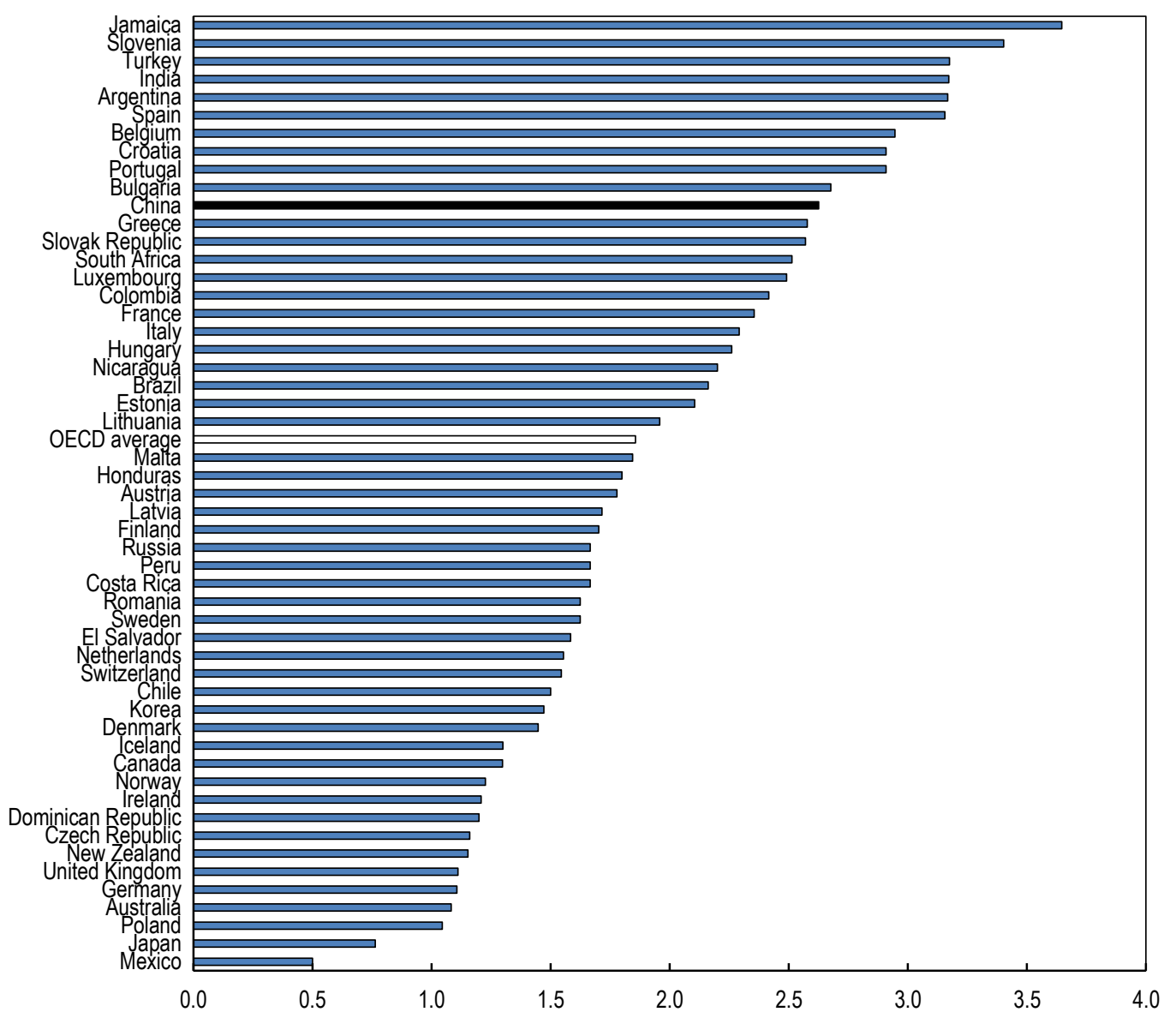

Note: The PMR sub-indicator of command-type regulation covers various regulations of coercive type such as shop opening hours universal service provision, backhauling, intermodal operations, advertising and restrictions on the legal form of business in eight sectors. The values of the indicator range between 0 and 6 , with higher values indicating more stringent regulation. The reported indicators for Brazil, China, India, Mexico, Poland, the Russian Federation and Turkey are based on preliminary estimates as some of the underlying data has not been validated with national authorities. Subsequent data revisions may lead to revisions to the indicators for these countries.

Source: OECD (2013) Product Market Regulation Database.

39. The administrative burden on start-ups, in particular on sole proprietor firms is very high in China (Figure 20), particularly hindering the development of professional services that are likely to choose this form of business. This not only hinders entrepreneurship but also inhibits employment creation, especially of young graduates who would be more likely to choose this form of starting a business. 
Figure 20. The administrative burden on sole proprietorship start-ups is prohibitively high

Product market regulation indicator, 2013

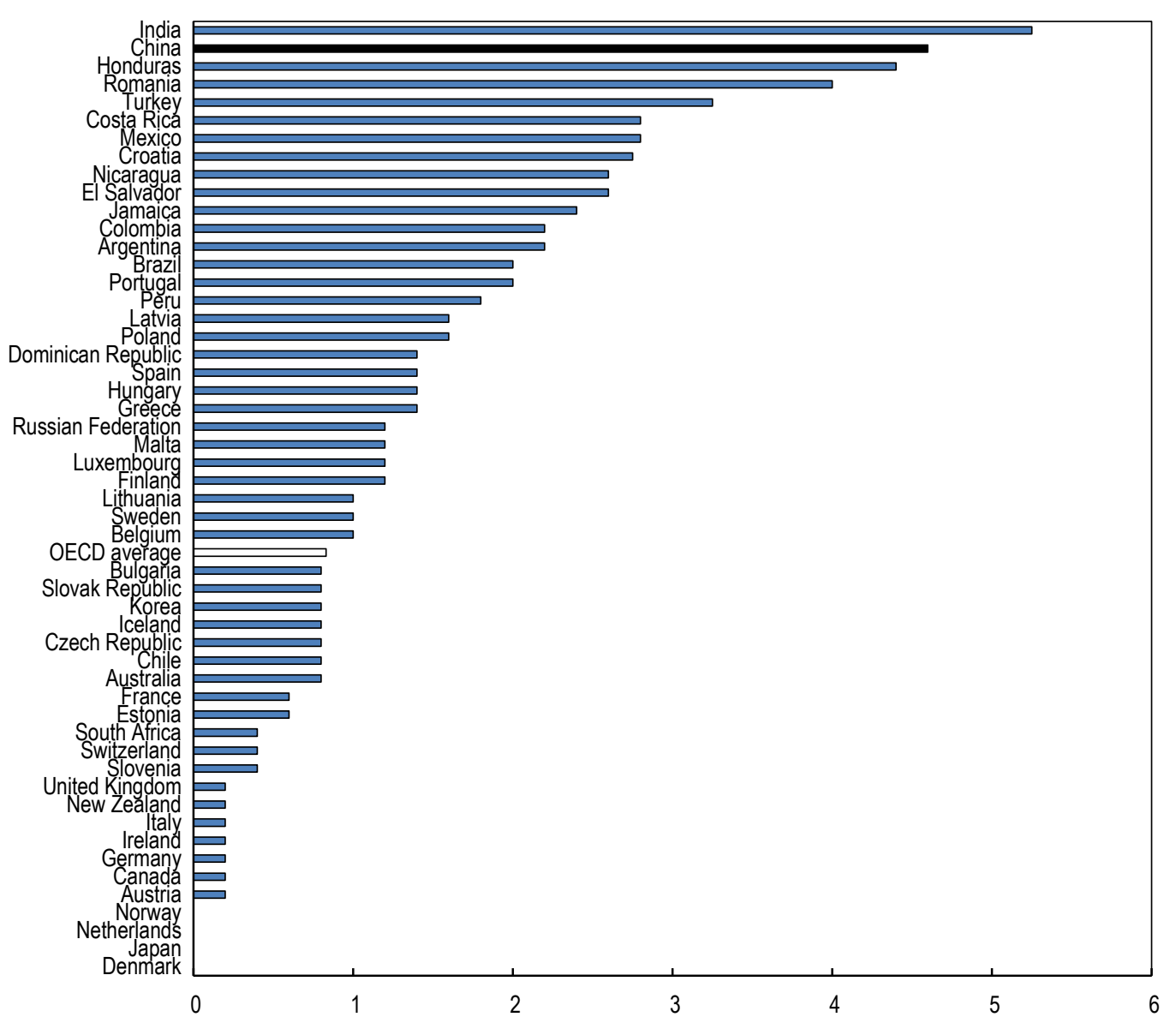

Note: The PMR sub-indicator of administrative burden on sole proprietor start-ups covers the number of procedures and bodies, the length of time required and the costs of the pre-registration and registration processes as well as minimum capital requirements. The values of the indicator range between 0 and 6 , with higher values indicating more stringent regulation. The reported indicators for Brazil, China, India, Mexico, Poland, the Russian Federation and Turkey are based on preliminary estimates as some of the underlying data has not been validated with national authorities. Subsequent data revisions may lead to revisions to the indicators for these countries.

Source: OECD (2013) Product Market Regulation Database.

40. In contrast to most other regulations, education requirements to provide accounting and legal services are lower in China than in most OECD countries. While in OECD countries at least a university degree is required to provide those services, in China secondary-school graduates can provide the service as long as they have the qualifications. Some qualification-related entry rules may be legitimate and even efficient in order for consumers to obtain low-cost assurance about the competence of service providers.

41. According to the STRI, trade in architecture services is hindered by restrictions to movement of people and on foreign entry, and by a lack of regulatory transparency (Figure 21) (Geloso Grosso et al., 2014a). The score for China is higher than for most OECD countries (indicating more restrictive regulations), but it is lower than for Brazil, India, Indonesia, Russia or South Africa. Trade in engineering services is hampered by the same types of regulations as in architecture and is more restrictive relative to other countries' regulations (Figure 22). 
Figure 21. Trade in architecture services is mainly hindered by restrictions on movement of people

STRI, 2013

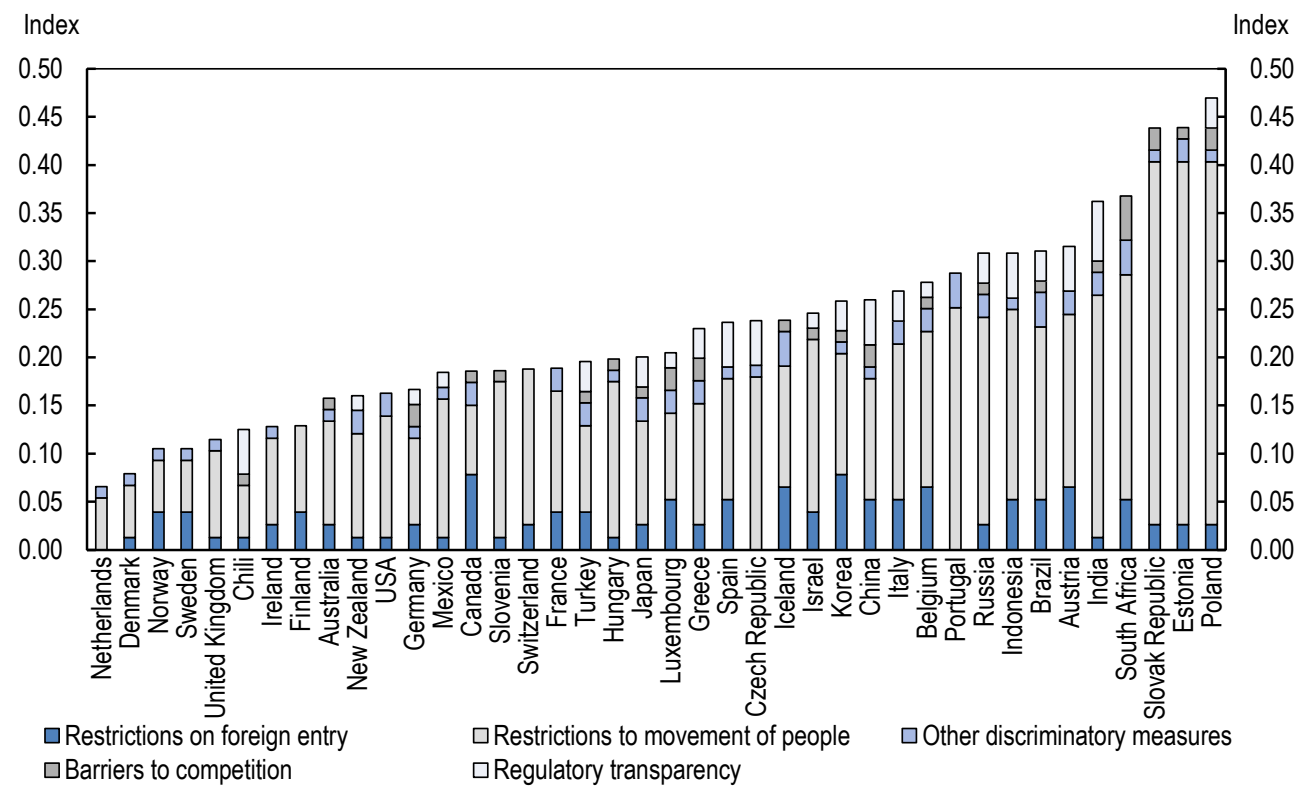

Note: The Services Trade Restrictiveness Index takes values between 0 and 1, with higher values indicating more stringent regulations.

Source: OECD Services Trade Restrictiveness Index database.

Figure 22. Restrictions on movement of people are also hindering trade in engineering services

STRI, 2013

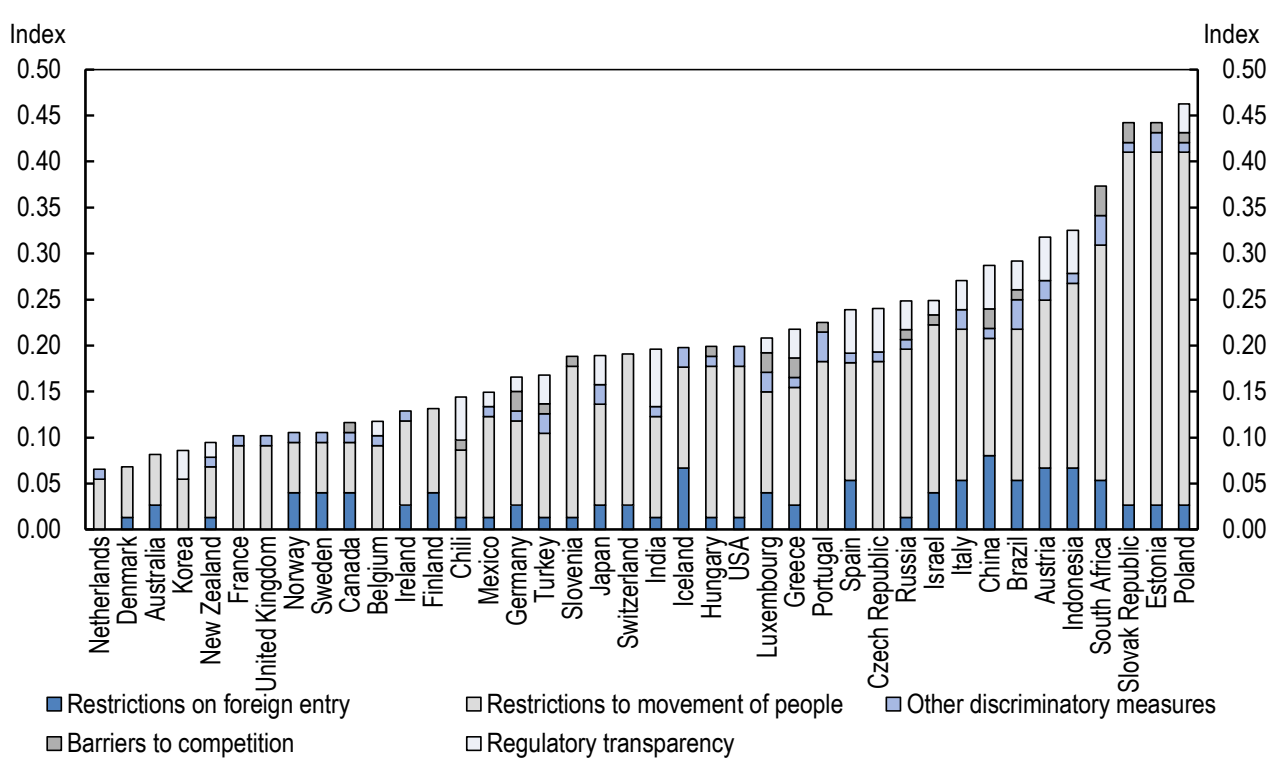

Note: The Services Trade Restrictiveness Index takes values between 0 and 1, with higher values indicating more stringent regulations.

Source: OECD Services Trade Restrictiveness Index database. 
42. When looking at the productivity of selected professional service firms, it appears that for law firms size matters a lot. Although there are no law firms with more than 1000 employees, the next size category, with 250-999 employees, is considerably more productive than the smaller-scale firms (Figure 23.A). Experience appears to count for productivity, but law firms older than 15 years appear to be somewhat less productive than somewhat younger ones (Figure 23.B). Legal service productivity appears to be high in areas with a flourishing private sector such as Shanghai, Shandong, Jiangsu and Zhejiang, but also in some less developed Central and Western ones such as Jiangxi and Inner Mongolia (Figure 23.C). Accounting services exhibit similar productivity patters: large firms are much more productive than smaller ones, though productivity increases with age (Figure 24.A and B). The provinces that have the highest productivity firms in legal services appear to have the most productive firms in accounting as well (Figure 24.C). In architecture and engineering services, similarly to accounting, larger and older firms tend to be more productive (Figure 25.A and B). Also, the same provinces seem to have the most productive firms in architecture and engineering services as in accounting or legal services (Figure 25.C).

Figure 23. Size and experience matter for law firm productivity

Median revenue by firm size, age and province, 2008
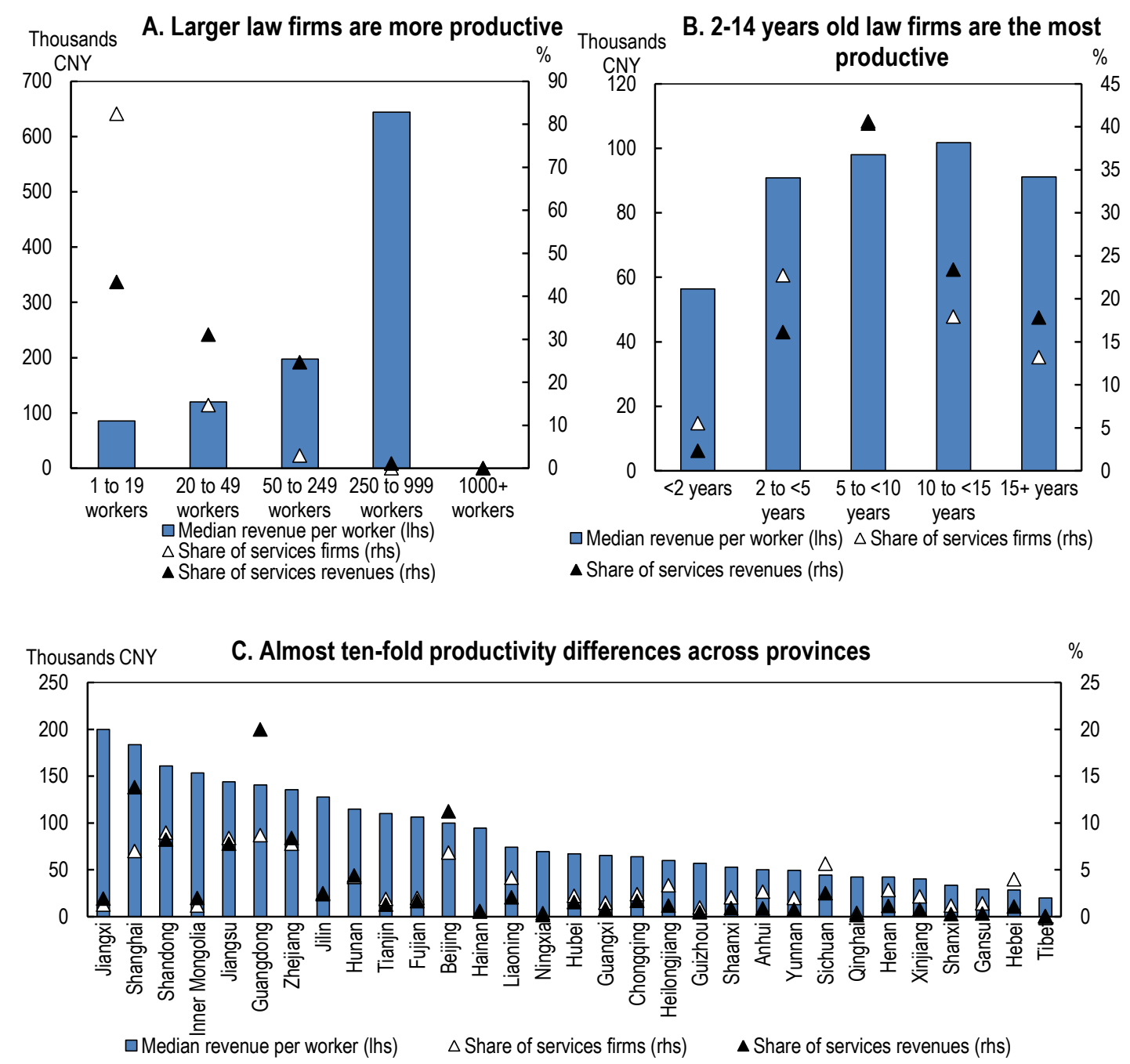

Note: Legal services include firms in category 7411 under the United Nations ISIC Rev. 3 classification.

Source: Authors' calculations based on the 2008 Economic Census. 
Figure 24. Larger and older accounting firms are more productive

Median revenue per worker by firm size, age and province, 2008

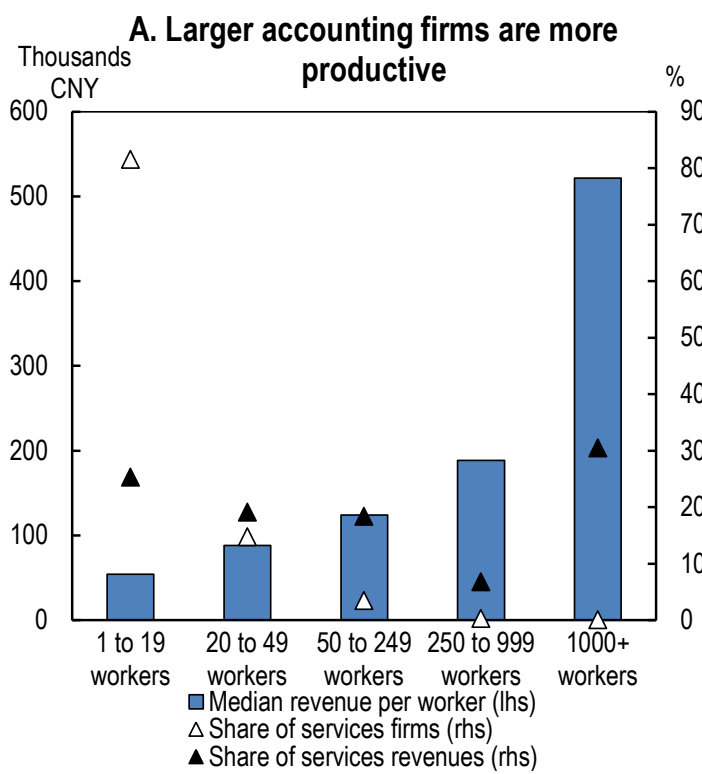

\section{B. Productivity increases with}

Thousands experience

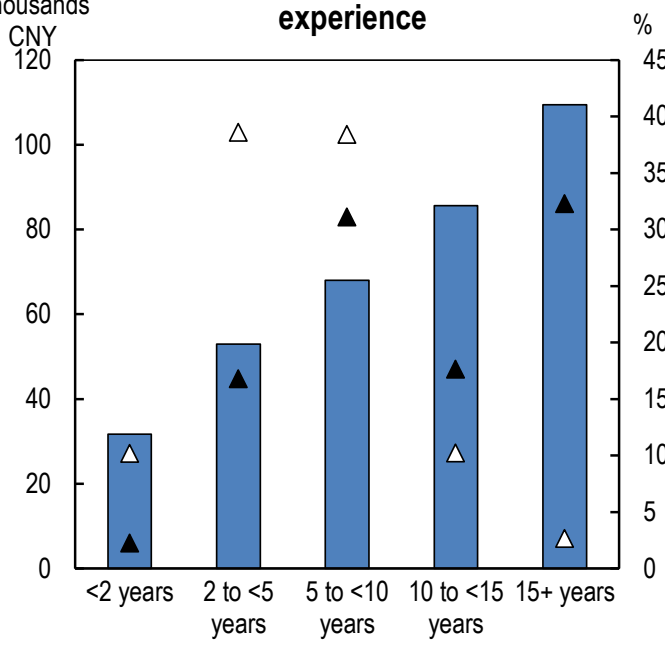

$\square$ Median revenue per worker (lhs) $\triangle$ Share of services firms (rhs)

$\Delta$ Share of services revenues (rhs)

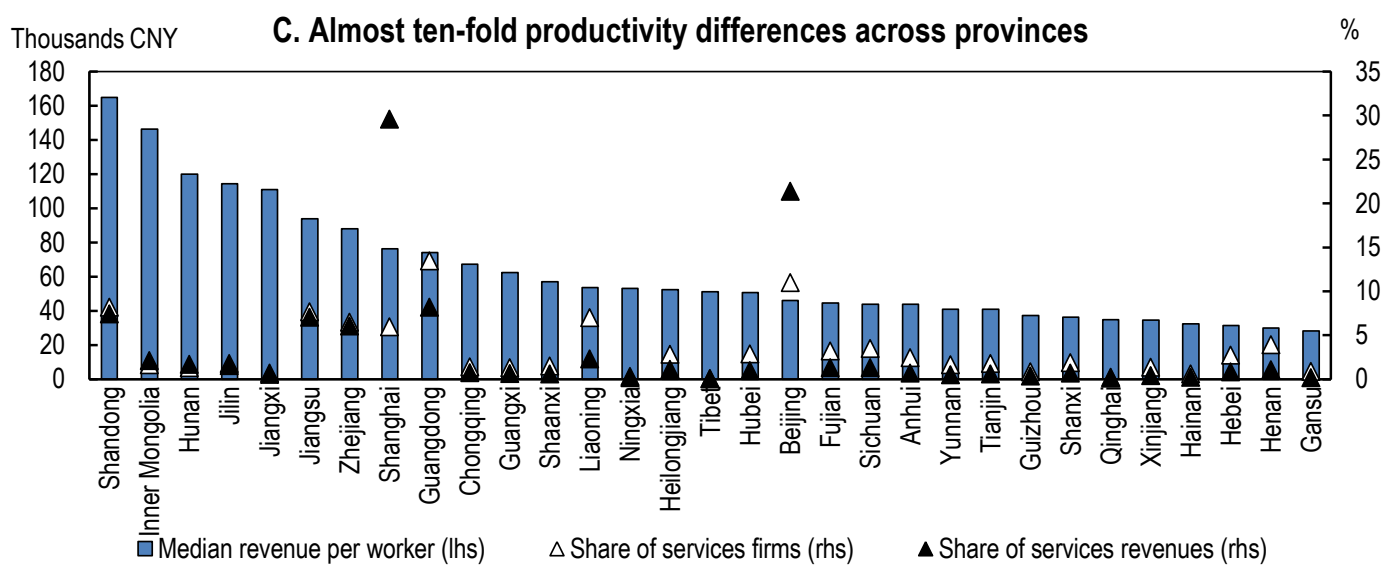

Note: Accounting services include firms in category 7412 under the United Nations ISIC Rev. 3 classification.

Source: Authors' calculations based on the 2008 Economic Census. 
Figure 25. Large and well-established architecture and engineering firms are more productive Median revenue per worker by firm size, age and province

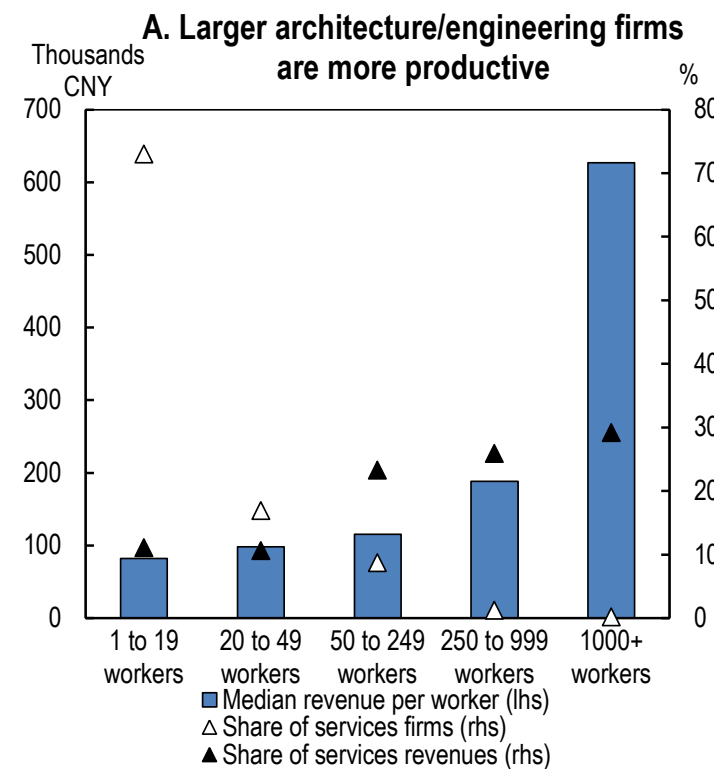

\section{B. Productivity increases with} Thousands experience

CNY experience \%

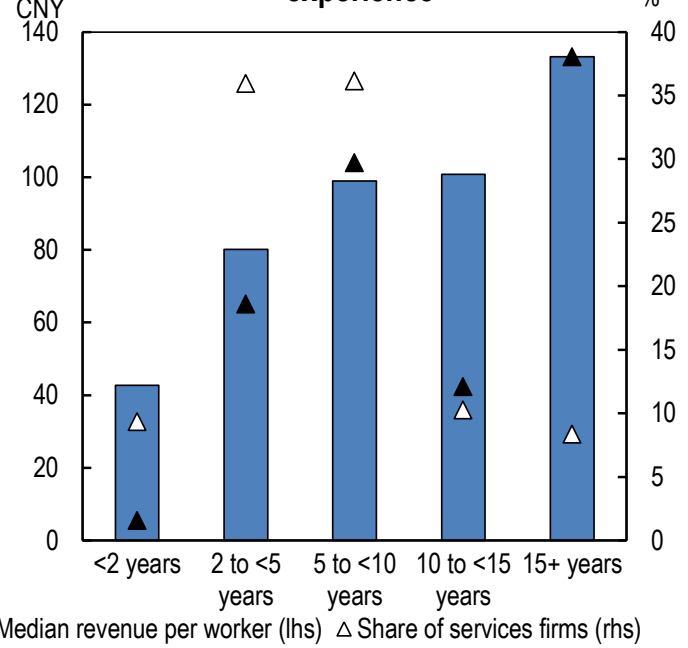

$\Delta$ Share of services revenues (rhs)

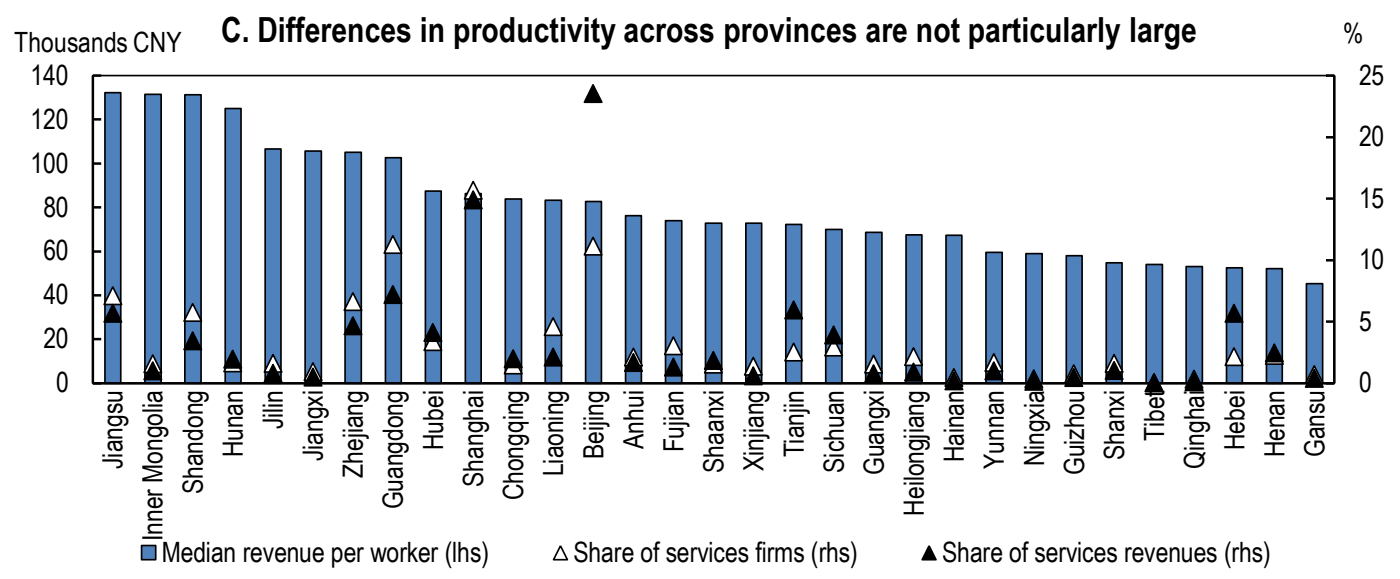

Note: Architecture and engineering services include firms in category 7421 under the United Nations ISIC Rev. 3 classification. Source: Authors' calculations based on the 2008 Economic Census. 


\section{Bibliography}

A. T. Kearney (2009), China Pursues Excellence in Logistics.

Chang, D. (2013), "The Development of the Service Industry in the Modern Economy: Mechanisms and Implications for China", China Finance and Economic Review, 1(3).

Deloitte and Development and Research Center of the State Post Bureau (2014), China's Express Sector Development Report 2014.

Geloso Grosso, M., I. Lejarraga, H. K. Nordas, F. Gonzales, S. Miroudot, A. Ueno, and D. Rouzet (2014a), "Services Trade Restrictiveness Index (STRI): Construction, Architecture and Engineering Services", OECD Trade Policy Papers, No. 170.

Geloso Grosso, M., H. K. Nordas, F. Gonzales, I. Lejarraga, S. Miroudot A. Ueno, and D. Rouzet (2014b), "Services Trade Restrictiveness Index (STRI): Legal and Accounting Courier Services", OECD Trade Policy Papers, No. 171.

Geloso Grosso, M., H. K. Nordas, A. Ueno, F. Gonzales, I. Lejarraga, S. Miroudot and D. Rouzet (2014c), "Services Trade Restrictiveness Index (STRI): Transport and Courier Services", OECD Trade Policy Papers, No. 176.

HSBC (2014), China Research - Sizing up the SOE Challenge.

KPMG (2011), On the Move in China - The Role of Transport and Logistics in a Changing Economy.

Molnar, M. and N. Bottini (2010), "How Large are Competitive Pressures in Services Markets? Estimation of Mark-ups in Selected OECD Countries", OECD Economic Journal, 2010(1).

National Bureau of Statistics of China and Office of the Leading Group of the State Council for the Third National Economic Census (2014), Di Sanci Quanguo Jingji Pucha Zhuyao Shuju Gongbao (Communique on Major Data of the Second National Economic Census) http://www.stats.gov.cn/tjsj/zxfb/201412/P020141216347816258498.pdf

Nordas, H. K. and D. Rouzet (2015), "The Impact of Services Trade Restrictiveness on Trade Flows: First Estimates", OECD Trade Policy Papers, forthcoming.

OECD (2014), Perspectives on Global Development - Boosting Productivity to Meet the Middle-Income Challenge, OECD, Paris.

Office of the Leading Group of the State Council for the Second National Economic Census and National Bureau of Statistics of China (2010), Communiqué on Major Data of the Second National Economic Census of China, China Statistics Press.

Price Waterhouse Coopers (2012), Logistics in China: An All-inclusive Market?

Ueno, A., M. Geloso Grosso, I. Lejarraga, H. K. Nordas, S. Miroudot, F. Gonzales, and D. Rouzet (2014), "Services Trade Restrictiveness Index (STRI): Distribution Services", OECD Trade Policy Papers, No. 172.

Wang, Q. (2013), Zhongguo Lingshouye Fazhan Jiance yu Fenxi Baogao (Report on the Development of China's Retailing), Renmin University Publishing, Beijing.

Zhang, Y. (2011), Zhuanxing yu Tuqi: Quanqiu Shiyexiade Zhongguo Fuwu Jingji (Transformation and Take-off: China's Service Economy in the New Era of Globalization), Social Sciences Academic Press, Beijing.

Zito, M. (2014), "Logistics, Warehousing and Transportation in China (Part 2)", http://www.chinabriefing.com/news/2014/06/17/logistics-warehousing-transportation-china-part-2.html 


\section{WORKING PAPERS}

The full series of Economics Department Working Papers can be consulted at www.oecd.org/eco/workingpapers

1216. Does the post-crisis weakness of global trade solely reflect weak demand?

(May 2015) by Patrice Ollivaud and Cyrille Schwellnus

1215. Estonia: raising productivity and benefitting more from openness

(May 2015) by Andreas Kappeler

1214. Estonia: making the most of human capital

(May 2015) by Andrés Fuentes Hutfilter

1213. The Czech labour market: documenting structural change and remaining challenges

(May 2015) by Sónia Araújo and Petr Malecek

1212. Reforming the Slovak public sector

(April 2015) by Lilas Demmou and Robert Price

1211. Spurring growth in lagging regions in the Slovak Republic

(April 2015) by Lilas Demmou, Gabriel Machlica and Martin Haluš

1210. Skill mismatch and public policy in OECD countries

(April 2015) by Müge Adalet McGowan and Dan Andrews

1209. Labour market mismatch and labour productivity: evidence from PIAAC data

(April 2015) by Müge Adalet McGowan and Dan Andrews

1208. Maintaining an efficient and equitable housing market in Belgium

(April 2015) by Sanne Zwart

1207. Determinants of the low female labour force participation in India

(April 2015) by Piritta Sorsa, Jan Mares, Mathilde Didier, Caio Guimaraes, Marie Rabate,

Gen Tang and Annamaria Tuske

1206. Strengthening skill use and school-to-work transitions in the Czech Republic

(April 2015) by Sónia Araújo and Petr Malecek

1205. Reforming the tax on immovable property: taking care of the unloved

(April 2015) by Hansjörg Blöchliger

1204. Taxation and investment in Colombia

(April 2015) by Sarah Perret and Bert Brys

1203. Efficiency and contestability in the Colombian banking system

(April 2015) by Christian Daude and Julien Pascal 
1202. Fiscal decentralisation in Colombia: new evidence regarding sustainability, risk sharing and "fiscal fatigue"

(April 2015) by Guillaume Bousquet, Christian Daude and Christine de la Maisonneuve

1201. Effects of economic policies on microeconomic stability

(April 2015) by Boris Cournède, Paula Garda and Volker Ziemann

1200. The 2013 update of the OECD's database on product market regulation - policy insights for $O E C D$ and non-OECD countries

(April 2015) by Isabell Koske, Isabelle Wanner, Rosamaria Bitetti and Omar Barbiero

1199. Improving taxes and transfers in Australia

(April 2015) by Philip Hemmings and Annamaria Tuske

1198. Federal-state relations in Australia

(April 2015) by Vassiliki Koutsogeorgopoulou and Annamaria Tuske

1197. Sharing the fruits of growth with all Mexicans

(April 2015) by Eduardo Olaberriá and Valéry Dugain

1196. What makes Mexicans happy?

(April 2015) by Valéry Dugain and Eduardo Olaberriá

1195. Improving the labour market integration of immigrants in Belgium

(March 2015) by Álvaro Pina, Vincent Corluy and Gerlinde Verbist

1194. Raising the potential of the domestically oriented sector in Germany

(March 2015) by André Eid and Andrés Hutfilter

1193. Improving transport infrastructure in Russia

(March 2015) by Alexander Kolik, Artur Radziwill and Natalia Turdyeva

1192. Improving the business climate in Russia

(March 2015) by Arthur Radziwill and Yana Vaziakova

1191. Determinants of female entrepreneurship in India

(March 2015) by Arnaud Daymard

1190. The changing role of the exchange rate for macroeconomic adjustment

(March 2015) by Patrice Ollivaud, Elena Rusticelli and Cyrille Schwellnus

1189. Boosting productivity in Russia: skills, education and innovation

(March 2015) by Lilas Demmou and Andreas Wörgötter

1188. Boosting growth and reducing informality in Mexico

(March 2015) by Sean Dougherty

1187. The conduct of monetary policy in the future: instrument use

(March 2015) by Kei-Ichiro Inaba, Rory O'Farrell, Łukasz Rawdanowicz and

Ane Kathrine Christensen 